\title{
Late Paleoproterozoic and Mesoproterozoic magmatism of the Nico Pérez Terrane (Uruguay): Tightening up correlations in southwestern Gondwana
}

Sebastián Oriolo $^{\mathrm{a} *}$, Pedro Oyhantçabal ${ }^{\mathrm{b}}$, Jiř́ Konopásek ${ }^{\mathrm{c}, \mathrm{d}}$, Miguel A.S. Basei ${ }^{\mathrm{e}}$, Robert Frei ${ }^{\mathrm{f}}$ Jiří Sláma $^{\mathrm{g}}$, Klaus Wemmer ${ }^{\mathrm{h}}$, Siegfried Siegesmund ${ }^{\mathrm{h}}$

${ }^{\text {a }}$ CONICET-Universidad de Buenos Aires. Instituto de Geociencias Básicas, Aplicadas y Ambientales de Buenos Aires (IGEBA), Intendente Güiraldes 2160, C1428EHA Buenos Aires, Argentina

${ }^{\mathrm{b}}$ Departamento de Geodinámica Interna, Facultad de Ciencias, Universidad de la República, Iguá 4225, 11400 Montevideo, Uruguay

${ }^{c}$ Department of Geosciences, UiT The Arctic University of Norway in Troms $\emptyset$, Dramsveien 201, 9037 Troms $\varnothing$, Norway

${ }^{\mathrm{d}}$ Czech Geological Survey, Klárov 3, 11821 Prague 1, Czech Republic

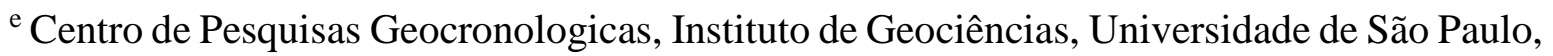
Rua do Lago 562, CEP 05508-080 São Paulo, Brazil

${ }^{\mathrm{f}}$ Department of Geosciences and Natural Resource Management, University of Copenhagen, Øster Voldgade 10, 1350 Copenhagen, Denmark

g Institute of Geology of the Czech Academy of Sciences, Rozvojová 269, 16500 Prague 6, Prague, Czech Republic

h Geoscience Center, Georg-August-Universität Göttingen, Goldschmidtstraße 3, 37077 Göttingen, Germany

*Corresponding author: seba.oriolo@gmail.com, soriolo@gl.fcen.uba.ar

\begin{abstract}
New geochronological, isotopic and geochemical data were obtained from the late Paleoproterozoic and Mesoproterozoic magmatic units of the Nico Pérez Terrane (Uruguay). A U-Pb LA-ICP-MS zircon age of $1768 \pm 11$ Ma confirms the Statherian age for the Illescas rapakivi intrusion, being thus comparable with the age of the Campanero Unit felsic orthogneisses. Though both the Illescas and Campanero intrusions exhibit dominantly granitic, meta- to peraluminous compositions, the first shows a dominant shoshonitic and ferroan composition, whereas high-K calc-alkaline and magnesian to ferroan compositions characterize orthogneisses of the Campanero Unit. Additionally, Sm/Yb and LaN/Y $\mathrm{Yb}_{\mathrm{N}}$ ratios indicate that both suites were emplaced in a thickened crust, whereas Lu-Hf zircon data of the Illescas granite together with available Sm-Nd data of the Campanero Unit point to significant recycling of an older, Archean and/or Paleoproterozoic crust of the Nico Pérez Terrane. Results suggest a common origin for both the Illescas and Campanero magmatism,
\end{abstract}


probably related to a post-collisional/post-orogenic setting. On the other hand, metagabbros of the Zanja del Tigre Complex present U-Pb LA-ICP-MS zircon ages of $1479 \pm 4$ and 1482 $\pm 6 \mathrm{Ma}$ and tholeiitic gabbroic compositions. Geochemical and $\mathrm{Sm}-\mathrm{Nd}$ isotopic data show similarities with LIP-related intracontinental mafic magmatism, suggesting a mixed magma source derived from depleted asthenosphere and fertile subcontinental lithospheric mantle contributions. Emplacement of the metagabbros was related to lithospheric extension in a continental rifting setting and, therefore, fertilization of the lithospheric mantle probably took place during older Paleoproterozoic subduction-related events. Coeval late Paleoproterozoic and early Mesoproterozoic magmatism is also recorded in the northern Nico Pérez Terrane of southernmost Brazil, and in basement inliers of the Kaoko Belt and the Angolan Shield (southwestern Congo Craton), thus suggesting a common evolution of these blocks prior to the Neoproterozoic.

Keywords: rapakivi granites, shoshonitic to high-K calc-alkaline magmatism, juvenile magmatism, Mesoproterozoic extension, Nuna supercontinent, coupled U-Pb \& Lu-Hf zircon data

\section{Introduction}

In last years, correlations of the Precambrian basement across the South Atlantic Ocean have been significantly tightened up, mostly based on similarities in the Archean, early Paleoproterozoic and Neoproterozoic record (e.g., Basei et al., 2005, 2008, 2011; Goscombe and Gray, 2007, 2008; Oyhantçabal et al., 2009, 2011a; Konopásek et al., 2014, 2016, 2017, 2018; Oriolo et al., 2016a, 2016b). However, two distinct magmatic events are recorded in the African Congo Craton at ca. 1.77-1.75 and 1.53-1.45 Ga, which so far have not been clearly documented in the South American counterpart (Kröner et al., 2003), challenging the validity of these correlations.

The Nico Pérez Terrane of Uruguay and Brazil, South America, is one of the main basement inliers of the Dom Feliciano Belt, which underwent significant crustal recycling processes during the late Neoproterozoic Brasiliano Orogeny, related to the assembly of southwestern Gondwana (Oriolo et al., 2016a, 2017; Basei et al., 2018; Oyhantçabal et al., 2018a). This block is essentially made up of an Archean and Rhyacian basement, which was strongly reworked by late Neoproterozoic metamorphism, deformation and granitic magmatism (Oyhantçabal et al., 2011b, 2012, 2018a; Oriolo et al., 2016a, 2016c; Hueck et al., 2017; Lara et al., 2017; Masquelin et al., 2017). Subordinate late Paleoproterozoic and 
Mesoproterozoic magmatism is recorded as well (Bossi and Campal, 1992; Mallmann et al., 2007; Gaucher et al., 2011), though its petrogenesis and tectonic setting still remain uncertain. Furthermore, the late Paleoproterozoic-Mesoproterozoic paleogeography of the Nico Pérez Terrane in the global context of supercontinent assembly and break-up is still unknown (e.g., Evans and Mitchell, 2011; Zhang et al., 2012; Pisarevsky et al., 2014).

In this contribution, new U-Pb LA-ICP-MS and Lu-Hf zircon, and whole-rock Sm$\mathrm{Nd}$ and geochemical data of so far poorly studied late Paleoproterozoic and Mesoproterozoic magmatic units of the Nico Pérez Terrane are presented, in order to determine the timing, petrogenesis and tectonic setting of both suites. Additionally, these units are compared with contemporaneous magmatism in other regions of South America and southern Africa, providing insights into the late Paleoproterozoic-Mesoproterozoic tectonic and paleogeographic evolution of southwestern Gondwana blocks.

\section{Geological setting}

The Nico Pérez Terrane (Bossi and Campal, 1992) is exposed in Uruguay and southeastern Brazil and is separated from the Río de la Plata Craton by the Sarandí del Yí Shear Zone (Fig. 1; Oriolo et al., 2015, 2016b). In contrast to the Río de la Plata Craton, which is made up of Paleoproterozoic rocks and underwent cratonization during the late Paleoproterozoic (Cingolani, 2011; Oyhantçabal et al., 2011b, 2018b), the Nico Pérez Terrane comprises a protracted Archean to Ediacaran geological record, supporting its allochthony with respect to the former (Oyhantçabal et al., 2011b, 2018a; Oriolo et al., 2016a). Furthermore, both blocks were amalgamated along the Sarandí del Yí Shear Zone during the late Neoproterozoic Brasiliano Orogeny, giving rise to crustal reworking and metacratonization of the Nico Pérez Terrane (Oriolo et al., 2015, 2016b, 2017; Oyhantçabal et al., 2018a).

The basement of the Nico Pérez Terrane essentially consists of Archean and Paleoproterozoic rocks, intruded by several late Neoproterozoic granitoids (Santos et al., 2003; Oyhantçabal et al., 2011b, 2012, 2018a; Oriolo et al., 2016a; Lara et al., 2017). In Uruguay, two main domains were defined for the Nico Pérez Terrane, namely the Cerro 
Chato and Pavas blocks, though some relics are also observed as basement inliers within the Neoproterozoic rocks of the Dom Feliciano Belt (Fig. 1; Oyhantçabal et al., 2018a).

The Cerro Chato Block is made up of Rhyacian high-grade orthogneisses of the Valentines-Rivera Granulitic Complex, and supracrustal rocks of the Vichadero and Valentines formations (Ellis, 1998; Santos et al., 2003; Oyhantçabal et al., 2011b, 2012, 2018a; Oriolo et al., 2016a; Rosiére et al., 2018). The Valentines-Rivera Granulitic Complex is intruded by the Illescas rapakivi granite (Fig. 2a), which yielded a Rb-Sr whole-rock age of $1760 \pm 32 \mathrm{Ma}$ (Bossi and Campal, 1992) and a comparable conventional ${ }^{207} \mathrm{~Pb} /{ }^{206} \mathrm{~Pb}$ zircon age of ca. $1.75 \mathrm{Ga}$ (Campal and Schipilov, 1995). Based on scarce geochemical data, Gaucher and Blanco (2014) indicated an intraplate setting for this intrusion.

To the southeast, the Cerro Chato Block is bounded by the Sierra de Sosa Shear Zone (Oriolo et al., 2016c), which separates it from the Pavas Block. The latter is constituted by Archean felsic orthogneisses, migmatites and metamafic rocks of the La China Complex and metasedimentary rocks of the Las Tetas Complex (Oyhantçabal and Vaz, 1990; Hartmann et al., 2001; Gaucher et al., 2011; Oyhantçabal et al., 2011b, 2018a). Though the latter is assumed to be Neoarchean (Hartmann et al., 2001), its age is poorly constrained between a maximum sedimentation age of ca. 2.7 Ga indicated by detrital zircons (Hartmann et al., 2001) and a ca. 630-600 Ma metamorphic overprint constrained by Ar/Ar phlogopite and muscovite data (Oriolo et al., 2016c).

Further basement relics occur as inliers in metasedimentary rocks of the Dom Feliciano Belt. The Campanero Unit is one of the largest basement inliers and comprises felsic orthogneisses (Fig. 2b), with scattered slivers of supracrustal rocks including amphibolites, micaschists, BIFs and migmatites (Sánchez-Bettucci, 1998; Sánchez-Bettucci et al., 2003; Oyhantçabal, 2005) that are interpreted as relics of the Las Tetas Complex. A U$\mathrm{Pb}$ conventional zircon age of $1735 \pm 32 \mathrm{Ma}$ (Sánchez-Bettucci et al., 2004) and a U-Pb SHRIMP zircon age of $1754 \pm 7$ Ma (Mallmann et al., 2007) were obtained for felsic orthogneisses of the Campanero Unit, both interpreted as the crystallization age of the protolith. Likewise, an Ar/Ar hornblende age of 564.0 \pm 4.1 Ma reported for an amphibolite provides a minimum Ediacaran age for metamorphism and cooling (Oyhantçabal et al., 2009). 
In addition, a Mesoproterozoic low- to medium-grade metavolcano-sedimentary sequence, namely the Zanja del Tigre Complex, is present within the schist belt of the Dom Feliciano Belt (Sánchez Bettucci and Ramos, 1999; Sánchez Bettucci et al., 2001; Oyhantçabal et al., 2005, 2018; Basei et al., 2008; Hueck et al., 2018). This unit comprises metapelites, dolomitic marbles, marls, metatuffs, metagabbros and metarhyolites, which were partially assigned to the Parque UTE and Mina Verdún groups (Poiré et al., 2003, 2005; Chiglino et al., 2008, 2010). However, due to the lack of well-exposed outcrops, penetrative deformation and metamorphism (Rossini and Legrand, 2003; Oyhantçabal et al., 2005), the term "Zanja del Tigre Complex" is preferred here. Besides, the Zanja del Tigre Complex is separated by a tectonic contact from the Campanero Unit (Rossini and Legrand, 2003). Oyhantçabal et al. (2005) reported U-Pb ID-TIMS zircon ages of $1492 \pm 4$ Ma from an intrusive metagabbro and $1429 \pm 21$ Ma from a metavolcanoclastic rock, whereas Gaucher et al. (2014) presented a U-Pb SIMS zircon age of $1461.8 \pm 3.9$ Ma from a metatuff (Oyhantçabal et al., 2018a). In addition, a U-Pb LA-ICP-MS zircon age of $1433 \pm 6$ Ma was obtained from a metarhyolite (Gaucher et al., 2011).

\section{Methodology}

Samples of late Paleoproterozoic and Mesoproterozoic igneous rocks were collected in the field, in order to carry out a systematic geochemical, isotopic and geochronological analysis (Electronic Appendix 1). Samples of metagabbros of the Zanja del Tigre Complex and Campanero orthogneisses were analysed at Activation Labs, using the package 4E Research INAA, Total Digestion - ICP, Lithium Metaborate/Tetraborate Fusion - ICP. In the case of the Illescas granite samples, major elements were measured with a PANanalytical Axios Advanced wavelength dispersive XRF spectroscope at the GeoForschungsZentrum Potsdam (GFZ). Crushed and dried samples were melted down to tablets with lithium tetraborate metaborate (Fluxana FX-X65), with a sample to flux ratio of 1:6. The $\mathrm{H}_{2} \mathrm{O}$ and $\mathrm{CO}_{2}$ contents were determined with a Vario EL III (Elementar Analysensysteme GmbH, Hanau). The determination of the sulfur content was carried out by an ELTRA CS 200 (ELTRA GmbH, Neuss). Trace element analyses were performed at the Geoscience Center of the Georg-August-Universität Göttingen with a Perkin Elmer DRC II Inductively Coupled 
Mass Spectrometer (ICP-MS). Analyses were validated by repeated independent sample preparation, blanks and analyses of two different international reference standards. Results were analysed using the GCDkit 4.1 software (Janoušek et al., 2006, 2016). Analytical data are presented in the Electronic Appendix 1.

Dating of zircon was carried out by the Laser Ablation Inductively Coupled Plasma Mass Spectrometry (LA-ICP-MS) in the laboratories of the University of São Paulo in Brazil (sample BUY 80-11), University of Bergen in Norway (sample UC-11) and at the Geological Institute of the Czech Academy of Sciences in Prague (sample UC-10). Description of zircon separation and particular analytical methods are provided in the Appendix 1. All isotopic data are reported in the Electronic Appendix 2. In the case of the sample BUY 80-11, Lu-Hf isotopic data were obtained as well (Appendix 1, Electronic Appendix 3).

Ten samples of metamafic rocks were selected for $\mathrm{Sm}-\mathrm{Nd}$ isotopic analyses at the Department of Geosciences and Natural Resource Management, University of Copenhagen, Denmark. Rock powders were repeatedly dissolved in $15 \mathrm{~mL}$ Savillex Teflon containers using a 1:1 mixture of concentrated aqua regia and concentrated $\mathrm{HF}$ on a hotplate at $130{ }^{\circ} \mathrm{C}$ for $72 \mathrm{~h}$. During the acid exposure period, samples were repetitively treated in an ultrasonic bath for a couple of minutes. Rock powders were spiked with a ${ }^{149} \mathrm{Sm}-{ }^{150} \mathrm{Nd}$ mixed spike, and the bulk REEs were separated over $15 \mathrm{~mL}$ glass stem columns charged with AG $50 \mathrm{~W}$ cation resin. REEs were further separated over $1.8 \mathrm{~mL}$ Ln resin (Eichrom ${ }^{\mathrm{TM}} \mathrm{LN}-\mathrm{B} 25-\mathrm{S}$ ) loaded in $0.8 \times 4 \mathrm{~cm}$ Poly-Prep ${ }^{\circledR}$ chromatography columns $\left(\operatorname{BioRad}^{\mathrm{TM}}\right)$ using 0.2 and 0.5 mol L ${ }^{-1} \mathrm{HCl}$. Sm-Nd isotope measurements were made on a VG Sector 54 IT thermal ionization mass spectrometer (TIMS). These isotopes were measured in a triple Ta-Re-Ta filament setting at center filament temperatures of $1750-1820^{\circ} \mathrm{C}$, applying both static $(\mathrm{Sm})$ and multidynamic $(\mathrm{Nd})$ routines for the collection of the isotopic ratios. $\mathrm{Nd}$ isotope ratios were normalized to ${ }^{146} \mathrm{Nd} /{ }^{144} \mathrm{Nd}=0.7219$. The mean value of ${ }^{143} \mathrm{Nd} /{ }^{144} \mathrm{Nd}$ for the JNdi-1 standard (Tanaka et al., 2000) during the measuring period was $0.512106 \pm 0.000010(\mathrm{n}=4$; $2 \sigma$ ). For further analytical details, see Frei and Polat (2013). Analytical results are presented in the Electronic Appendix 4.

\section{Results}




\subsection{Geochemistry}

\subsubsection{Late Paleoproterozoic magmatism}

The composition of samples of both the Illescas intrusion and the Campanero Unit correspond mostly to granites, though some samples of the latter plot in the granodiorite, quartz-monzonite and foid-syenite field (Fig. 3a; Middlemost, 1994), and show metaluminous to peraluminous and calc-alkaline compositions (Figs. 3b, c; Shand, 1943; Irvine and Baragar, 1971). On the other hand, shoshonitic and high-K calc-alkaline compositions are dominant for samples of the Illescas granite and Campanero Unit, respectively (Fig. 3d, Peccerillo and Taylor, 1976). In the classification scheme for granitic rocks of Frost et al. (2001), the Illescas granite and Campanero Unit show ferroan and dominantly magnesian to ferroan compositions, respectively (Fig. 4a), whereas both sets of samples present calc-alkalic to alkali-calcic compositions (Fig. 4b). However, it is important to outline to some samples of both suites record partial mobility of $\mathrm{K}_{2} \mathrm{O}$ and $\mathrm{Na}_{2} \mathrm{O}$, e.g., as recorded by the large dispersion of $\mathrm{K}_{2} \mathrm{O}$ for a given $\mathrm{SiO}_{2}$ value (Fig. 3d). Partial $\mathrm{K}_{2} \mathrm{O}, \mathrm{Na}_{2} \mathrm{O}$ and possibly $\mathrm{CaO}$ mobility is further supported by the W index (Ohta and Arai, 2007), which indicates moderate weathering of some samples. For this reason, petrogenetic inferences based on these elements must be considered with caution.

Trace elements normalized to primitive mantle (McDonough and Sun, 1995) of both Illescas and Campanero samples show a similar pattern with a moderately negative slope (Figs. 5a, b), though the former are generally more enriched in most elements than the latter. LILE are typically enriched with respect to HFSE, and marked negative anomalies of $\mathrm{Nb}$, Ta, P and Ti are observed as well. Chondrite-normalized REE patterns (Boynton, 1989) are also comparable for both sets of samples, showing enrichment of LREE with respect to HREE (Figs. 6a, b) and moderate REE fractionation (Illescas granite, $\mathrm{La}_{\mathrm{N}} / \mathrm{Yb}_{\mathrm{N}}=7.61$ to 33.87; Campanero Unit, $\mathrm{La}_{N} / \mathrm{Yb}_{\mathrm{N}}=4.83$ to 85.20). Additionally, negligible to slightly negative Eu anomalies are observed (Illescas granite, $\mathrm{Eu} / \mathrm{Eu}^{*}=0.42$ to 1.19; Campanero Unit, $\mathrm{Eu} / \mathrm{Eu}^{*}=0.64$ to 1.08$)$. There are, however, some variations in the REE patterns of both sets of samples, particularly in the case of the Campanero Unit. $\mathrm{Ce} / \mathrm{Yb}$ of the Illescas granite mostly varies between ca. 36 and 49, though two samples record values of ca. 20 and 90. In the case of the Campanero Unit, Ce/Yb values are scattered between ca. 31 and 196. 


\subsubsection{Mesoproterozoic magmatism}

Metamafic rocks show gabbroic metaluminous compositions (Figs. 3a, b; Middlemost, 1994; Shand, 1943). In both $\mathrm{AFM}$ and $\mathrm{SiO}_{2}$ vs $\mathrm{K}_{2} \mathrm{O}$ diagrams (Irvine and Baragar, 1971; Peccerillo and Taylor, 1976), they show a clear tholeiitic affinity (Figs. 3c, d).

Trace elements show a relatively flat pattern and, though HFSE concentrations are comparable to those expected for a N-MORB (Fig. 5c; Sun and McDonough, 1989), there is a significant enrichment in LILE ( $\mathrm{Cs}, \mathrm{Rb}, \mathrm{Ba}, \mathrm{Pb}$ ) and a slight enrichment in $\mathrm{Th}, \mathrm{U}$ and $\mathrm{Ta}$. On the other hand, a flat pattern with an enrichment of 5 to 20x regarding chondrite composition is also observed in REE (Boynton, 1989), revealing no significant REE fractionation (Fig. $6 c ; \mathrm{LaN}_{N} / \mathrm{Yb}_{\mathrm{N}}=0.85$ to 1.54 ). Slightly positive or negative Eu anomalies are present in some samples, despite being absent in most cases $\left(\mathrm{Eu} / \mathrm{Eu}^{*}=0.94\right.$ to 1.24$)$.

\subsection{Geochronology}

\subsubsection{Late Paleoproterozoic magmatism}

Sample BUY 80-11 was collected from the Illescas granite. This porphyritic intrusion is made up of K-feldspar, plagioclase, quartz and scarce biotite, with rapakivi texture and bluish quartz as the most conspicuous features (Fig. 2a). Zircon crystals are mostly prismatic and show oscillatory zoning (Fig. 7), which in some cases is observed in both core and rim. A concordant age of $1768 \pm 11$ Ma was obtained, considering 24 out of 26 zircon grains (Fig. 8a, Electronic Appendix), and interpreted as the age of crystallization.

\subsubsection{Mesoproterozoic magmatism}

Two samples of metamorphosed gabbroic rocks were collected for geochronological analysis. Sample UC 10 consists of a fine-grained matrix of recrystallized plagioclase, epidote, chlorite and titanite surrounding large crystals of actinolite and an opaque mineral. 
The rock also contains up to $2 \mathrm{~mm}$ large grains of quartz and it is not clear if the quartz was a part of the primary igneous mineral association of the sample, or if it represents dismembered quartz vein or even grains entrapped from the surrounding sedimentary rocks during intrusion. Sample UC 11 has a very similar mineral content to the sample UC 10 but lacks the large quartz grains.

Analyzed zircon grains from both samples are short prismatic crystals with oscillatory zoning or their fragments (Figs. 7), supporting their magmatic origin. Out of eighteen analyses of zircon grains from the sample UC 10, fifteen yielded similar isotopic data that combine into a concordia U-Pb age of $1479 \pm 4 \mathrm{Ma}$, which is interpreted as the crystallization age of the gabbroic melt. Three analyses yielded somewhat older dates that cluster around an age of $1.55 \mathrm{Ga}$ (Fig. 8b, Electronic Appendix). The LA-ICP-MS analysis of twenty-four zircon crystals from the sample UC 11 provided a tight cluster in the concordia diagram and the data combine in a U-Pb age of $1482 \pm 6 \mathrm{Ma}$ (Fig. 8c, Electronic Appendix), which is also interpreted as the time of crystallization of the magmatic protolith.

\subsection{Lu-Hf and Sm-Nd isotopic data}

Lu-Hf data were also obtained for zircons of sample BUY 80-11 of the Illescas granite. Statherian zircons yield $\varepsilon_{\mathrm{Hf}(\mathrm{t})}$ values scattered between -16.4 and -22.6 and dominant Paleoarchean model ages between ca. 3.3 and 3.6 Ga (Fig. 9, Electronic Appendix 3), pointing to a significant component of reworked older crust (see Section 5.1). On the other hand, Sm-Nd data of the metagabbros show positive $\varepsilon_{\mathrm{Nd}(\mathrm{t})}$ values between +3.46 and +5.99 , together with dominant late Paleoproterozoic model ages, though values scatter between ca. 1.6 and 2.5 Ga (Fig. 10, Electronic Appendix 4). These results indicate a juvenile mantlederived magma source, though the lowest $\varepsilon_{\mathrm{Nd}(\mathrm{t})}$ values and associated early Paleoproterozoic to Neoarchean model ages suggest a subordinate crustal contribution as well.

\section{Discussion}

\subsection{Petrogenesis and tectonic setting of the late Paleoproterozoic magmatism}


Scarce geochronological data for the Campanero Unit constrain the timing of granitic magmatism at $1754 \pm 7 \mathrm{Ma}$ (U-Pb SHRIMP zircon; Mallmann et al., 2007), whereas an age of $1760 \pm 32 \mathrm{Ma}$ was indicated for the Illescas rapakivi granite based on $\mathrm{Rb}-\mathrm{Sr}$ whole-rock data (Bossi and Campal, 1992). Due to the lack of further geochronological and geochemical data, the Illescas and Campanero magmatism was tentatively interpreted as the result of intraplate and arc magmatism, respectively (Oyhantçabal, 2005; Gaucher and Blanco, 2014). Moreover, it is still unclear if there is a link between these late Paleoproterozoic magmatic events and Rhyacian tectonometamorphic processes recorded by the Valentines-Rivera Granulitic Complex, implying multistage magmatism at ca. 2.18-2.10 Ga succeeded by highgrade metamorphism and crustal anatexis at ca. 2.10-2.00 Ga (Santos et al., 2003; Oyhantçabal et al., 2012; Oriolo et al., 2016a).

New geochronological data constrain the age of the Illescas rapakivi granite at 1768 $\pm 11 \mathrm{Ma}$ (Fig. 8a), thus confirming the late Paleoproterozoic age suggested by Rb-Sr wholerock and conventional ${ }^{207} \mathrm{~Pb} /{ }^{206} \mathrm{~Pb}$ zircon data (Bossi and Campal, 1992; Campal and Schipilov, 1995). On the other hand, geochemical data indicate that this intrusion essentially comprises meta- to peraluminous granites with ferroan and calc-alkalic to alkali-calcic compositions (Figs. 3, 4). Hence, the Illescas intrusion shows a clear affinity with subalkaline A-type magmatism (Frost et al., 2001), similarly to other rapakivi granites worldwide (e.g., Moore et al., 1993; Rämö and Haapala, 1995; Alviola et al., 1999; Costa et al., 2016). Additionally, this intrusion plots in the late- to post-orogenic field of the $\mathrm{R}_{1}-\mathrm{R}_{2}$ tectonic discrimination diagram of Batchelor and Bowden (1985), further supported by trace element compositions indicative of $\mathrm{A}_{2}$-type post-collisional magmatism (Fig. 11; Eby, 1992).

In the case of the Campanero Unit, felsic orthogneisses mostly correspond to metato peraluminous calc-alkaline to high-K calc-alkaline granites (Fig. 3). Compositions are dominantly magnesian to slightly ferroan, and calc-alkalic to alkali-calcic (Fig. 4; Frost et al., 2001). Similarly to the Illescas granite (Fig. 11a), orthogneisses plot in the late- to postorogenic field of the $\mathrm{R}_{1}-\mathrm{R}_{2}$ tectonic discrimination diagram of Batchelor and Bowden (1985).

In spite of some differences (Section 4.1.1), the Illescas granite (1768 $\pm 11 \mathrm{Ma})$ and orthogneisses of the Campanero Unit (1754 \pm 7 Ma; Mallmann et al., 2007) exhibit strong similarities in their geochemical fingerprint and show Statherian crystallization ages that 
suggest a common tectonomagmatic setting. They present common aspects in their major element geochemistry (Fig. 3), including also the potential tectonic setting (Fig. 11), together with comparable trace element and REE patterns (Figs. 5, 6). Additionally, both sets of samples present relatively high $\mathrm{Sm} / \mathrm{Yb}$ and $\mathrm{La}_{\mathrm{N}} / \mathrm{Yb}_{\mathrm{N}}$ (Fig. 12), indicative of a thickened crust (Mamani et al., 2010; Profeta et al., 2015; Hu et al., 2017). There are, however, some variations in these values, particularly in the Campanero Unit samples, similarly to $\mathrm{Ce} / \mathrm{Yb}$ (see Section 4.1.1). Such differences might result from differences in the source, probably arising from heterogeneities related to the inherited crustal component recorded by isotopic data (see below). Nevertheless, most geochemical proxies thus suggest a common origin for the Illescas and Campanero intrusions, probably related a post-collisional setting. Comparable associations of high-K calc-alkaline to shoshonitic magmatism are common in post-collisional settings, as reported by Liégeois et al. (1998), Oyhantçabal et al. (2007), Eyal et al. (2010) and Lan et al. (2012), among others.

Lu-Hf data of the Illescas granite point to dominant reworked crust, as revealed by $\varepsilon_{H f(t)}$ values between -16.4 and -22.6, and associated Archean model ages (Fig. 9, Electronic Appendix 3). When compared with Lu-Hf data of the Rhyacian Valentines-Rivera Granulitic Complex and Ediacaran magmatism of the Nico Pérez Terrane (Oriolo et al., 2016a), all three pulses of magmatism are aligned along an apparent crustal array with ${ }^{176} \mathrm{Lu} /{ }^{177} \mathrm{Hf}=0.015$, typical for a crustal reservoir (e.g., Griffin et al., 2002). Orthogneisses of the ValentinesRivera Granulitic Complex constitute the wall rock of the Illescas granite and host Archean zircon xenocrysts, similarly to Ediacaran intrusions (Oriolo et al., 2016a). Though subordinated mantle sources cannot be discarded, it can thus be inferred that the Illescas granite mostly resulted from melting of Archean rocks (e.g., Pavas Block; Hartmann et al., 2001; Oyhantçabal et al., 2011b, 2018a) and/or Paleoproterozoic orthogneisses of the Valentines-Rivera Granulitic Complex, being thus comparable with reworked crustal sources inferred for other rapakivi and $\mathrm{A}_{2}$-type intrusions (e.g., Eby, 1992; Heinonen et al., 2010, 2014; Peng et al., 2012; Scandolara et al., 2013). In addition, orthogneisses of the Campanero Unit present $\varepsilon_{\mathrm{Nd}(\mathrm{t})}$ values of -13.5 and -13.4 , with $\mathrm{T}_{\mathrm{DM}}$ of 2.84 and $3.05 \mathrm{Ga}$, respectively (Mallmann et al., 2007), further supporting a dominant reworked crustal source for the Late Paleoproterozoic magmatism of the Nico Pérez Terrane. 


\subsection{Petrogenesis and tectonic setting of the Mesoproterozoic magmatism}

If compared with the Paleo- and Neoproterozoic, the Mesoproterozoic record of the Nico Pérez Terrane is relatively scarce, being restricted to metavolcano-sedimentary rocks of the Zanja del Tigre Complex (Sánchez Bettucci and Ramos, 1999; Sánchez Bettucci et al., 2001; Oyhantçabal et al., 2005, 2018; Basei et al., 2008). Zircons yield U-Pb ID-TIMS multigrain crystallization ages of $1492 \pm 4$ and $1429 \pm 21$ Ma for gabbroic and rhyolitic intercalations (Oyhantçabal et al., 2005), respectively. In addition, a U-Pb SIMS zircon age of $1461.8 \pm 3.9 \mathrm{Ma}$ and a U-Pb LA-ICP-MS zircon age of $1433 \pm 6 \mathrm{Ma}$ were reported for metattufs (Gaucher et al., 2011, 2014). Due to the lack of further geological, geochemical and isotopic data, the tectonic setting of this early Mesoproterozoic volcano-sedimentary unit still remains speculative, and was alternatively interpreted as the result of collisional tectonics related to a Grenvillian tectonometamorphic event (Campal and Schipilov, 1999; Gaucher et al., 2011) or extensional tectonics (Oriolo et al., 2016a; Oyhantçabal et al., 2018a).

U-Pb LA-ICP-MS zircon ages of $1479 \pm 4$ and $1482 \pm 6 \mathrm{Ma}$ obtained for metagabbros of the Zanja del Tigre Complex confirm the middle Calymmian age for mafic magmatism (Fig. 8), being slightly older than associated rhyolites and tuffs (Oyhantçabal et al., 2005; Gaucher et al., 2011, 2014). Trace element and REE patterns present significant similarities with dolerite dykes of the Etendeka province (Trumbull et al., 2007) and low-Ti flood basalts of the Paraná (Peate and Hawkesworth, 1996), Karoo (Ware et al., 2018) and Morondava (Bardintzeff et al., 2010) provinces (Figs. 5, 6). Nb/Yb and Th/Yb ratios show that most samples plot above the MORB-OIB array (Fig. 13a), reflecting Th addition due to crustal contamination (Pearce, 2008). Together with $\mathrm{Nb} / \mathrm{Yb}$ vs $\mathrm{TiO}_{2} / \mathrm{Yb}$ data (Fig. 13b), metagabbros thus show compositions that are compatible with those recorded by continental rifting rocks (Pearce, 2008). Low Sm/Yb and $\mathrm{La}_{N} / \mathrm{Yb}_{\mathrm{N}}$ contrast significantly with those of the Late Paleoproterozoic intrusions (Fig. 12; Mamani et al., 2010; Profeta et al., 2015; Hu et al., 2017), pointing to lithospheric thinning, as expected for an extensional setting.

Geochemical and Sm-Nd data reveal mantle-derived magmas as the main source for the metagabbros, though Th and LILE enrichment together with the Sm-Nd fingerprint accounts for a crustal component to some extent, compatible with those reported for 
continental rifting (Fig. 13; Pearce, 2008). For back-arc basin basalts, Pearce and Stern (2006) summarized different mechanisms to explain crustal signatures in asthenospherederived magmas (e.g., Davies and Stevenson, 1992; Elliott et al., 1997; Taylor and Martinez, 2003; Pearce et al., 2005), which are based on different sources for the crustal component and can be evaluated based on $\mathrm{Nb} / \mathrm{Ta}, \mathrm{Th} / \mathrm{Ta}, \mathrm{Th} / \mathrm{Nb}, \mathrm{Ba} / \mathrm{Th}$ and $\mathrm{Ba} / \mathrm{Nb}$ ratios (Pearce et al., 2005; Pearce and Stern, 2006).

In metamafic rocks of the Nico Pérez Terrane, most Nb/Ta ratios vary between 12 and 18, with relative homogeneous $\mathrm{Th} / \mathrm{Ta}(0.6-2.7)$ and $\mathrm{Th} / \mathrm{Nb}(0.11-0.21)$, and significantly higher $\mathrm{Ba} / \mathrm{Nb}$ ratios $(>60)$ (Electronic Appendix 1). In the first place, low $\mathrm{Nb} / \mathrm{Ta}$ ratios allow ruling out contamination of asthenosphere-derived magmas by incorporation of continental lithosphere as a possible source of the crustal signature, which is recorded by highly fractionated $\mathrm{Nb} / \mathrm{Ta}$ ratios (>20) (Pearce et al., 2005; Pearce and Stern, 2006). Low Th/Nb ratios suggest a negligible component of deep subduction, further supported by $\mathrm{Th} / \mathrm{Ta}$ and $\mathrm{Nb} / \mathrm{Ta}$ ratios that are similar to those of MORB (Pearce et al., 2005). In contrast, high $\mathrm{Ba} / \mathrm{Th}$ ratios suggest a significant contribution of shallow subduction (Fig. 14; Pearce et al., 2005; Pearce and Stern, 2006), though the subduction component might alternatively be inherited from an earlier subduction event, as in the case of the East Scotia Sea and the Manus Basin (Pearce and Stern, 2006).

In sum, geochemical and $\mathrm{Sm}-\mathrm{Nd}$ data provide robust evidence that Mesoproterozoic mafic rocks of the Nico Pérez derived from metasomatized asthenospheric magmas or, more likely, from a mixture of depleted asthenospheric and fertile subcontinental lithospheric mantle magmas, emplaced during lithospheric extension, similarly to LIP-related mafic magmatism (e.g., Peate and Hawkesworth, 1996; Bardintzeff et al., 2010; Ware et al., 2018). The most likely mechanism to explain its subduction fingerprint are contemporaneous shallow subduction or inheritance of an older subduction component (Pearce et al., 2005; Pearce and Stern, 2006), being thus compatible with both back-arc and continental rifting extensional settings. So far, no arc magmatism has been reported for the Nico Pérez Terrane and adjacent areas during the Mesoproterozoic (see also Section 5.3) and, consequently, inheritance seems to be the most probable explanation for the subduction component, which 
can be attributed to older, Paleoproterozoic tectonomagmatic events (e.g., Oyhantçabal et al., 2012, 2018a; Oriolo et al., 2016) that might fertilize the subcontinental lithospheric mantle.

\subsection{Regional implications}

Geochemical, geochronological and isotopic data indicate a common origin for the Illescas granite and the Campanero Unit, probably linked to a Statherian post-collisional setting and a thickened continental crust (Section 5.1). A priori, this granitic magmatism might be interpreted as the result of the major tectonometamorphic event recorded by the Valentines-Rivera Granulitic Complex, implying high-grade metamorphism and crustal anatexis at ca. 2.1-2.0 Ga (Santos et al., 2003; Oyhantçabal et al., 2012; Oriolo et al., 2016a). Retrograde metamorphism is constrained by $\mathrm{Th}-\mathrm{U}-\mathrm{Pb}$ CHIME-EPMA monazite and U-Pb LA-ICP-MS zircon overgrowth ages at ca. 1.98-1.80 Ga (Oyhantçabal et al., 2012; Oriolo et al., 2016). Though these latter ages fill the record between the ca. 2.2-20 and 1.8-1.7 Ga magmatism, this magmatic gap of ca. 200 my may suggest that both events were not related and, consequently, Statherian magmatism might record a distinct event in the evolution of the Nico Pérez Terrane.

In the Brazilian counterpart of the Nico Pérez Terrane (Fig. 15; Oyhantçabal et al., 2018a), U-Pb LA-ICP-MS zircon ages of $1785 \pm 42,1768 \pm 24,1764 \pm 29$ and $1763 \pm 28$ Ma were obtained for the Seival metagranite, which comprises granodioritic, monzogranitic and leucogranitic intrusions with a post-collisional geochemical fingerprint (Camozzato et al. 2013, 2017; Oyhantçabal et al., 2018a). Similarly, underformed granites of the Taquarembó Block yield U-Pb LA-ICP-MS zircon ages of $1840 \pm 13$ and $1766 \pm 14 \mathrm{Ma}$ (Girelli et al. 2016a, b; Philipp et al. 2017). Further north, the Apiaí Domain of the Ribeira Belt hosts mylonitic granodiorites and syenogranites yielding U-Pb TIMS zircon multigrain ages of $1772 \pm 11$ and $1752 \pm 9 \mathrm{Ma}$ (Cury et al., 2002; Prazeres Filho, 2005), whereas a U$\mathrm{Pb}$ TIMS zircon multigrain age of $1790 \pm 22 \mathrm{Ma}$ was obtained for associated metabasic rocks (Siga Jr. et al., 2011a). Based on geochemical data, Cury et al. (2002) and Siga Jr et al. (2011a) interpreted a post-orogenic or intraplate setting for this magmatism. 
Along the southwestern Atlantic coast of Africa (Fig. 15), late Orosirian-Statherian magmatism was also reported for the Kaoko Belt (Kröner et al., 2004; Luft et al., 2011). In the Western and Central Kaoko Zones, several SHRIMP and conventional U-Pb TIMS multigrain zircon ages of ca. 1.78-1.73 Ga were obtained for dominantly granitic and granodioritic orthogneisses (Kröner et al., 2004; Luft et al., 2011), which present $\varepsilon_{\mathrm{Nd}(\mathrm{t})}$ values between -2.05 and +4.30 (Luft et al., 2011). Additionally, felsic and subordinated mafic orthogneisses show calc-alkaline and tholeiitic compositions, interpreted as the result of island arc and oceanic island settings (Luft et al., 2011).

In a similar way, the Angolan Shield, which comprises the southwestern part of the Congo Craton, records not only late Paleoproterozoic intrusive magmatism but also deposition of volcano-sedimentary sequences (Fig. 15). An ignimbrite of the Humpata Formation of the Chela Group constrains the timing of sedimentation at $1798 \pm 11 \mathrm{Ma}$ (U$\mathrm{Pb}$ SHRIMP zircon; McCourt et al., 2013), whereas the crystallization of granitic, granodioritic and subordinated gabbroic orthogneisses of the Epupa Complex is constrained at ca. 1.86-1.75 Ga based on SHRIMP and conventional U-Pb TIMS multigrain zircon data (Kröner et al., 2010, 2015). Geochemical data show typical calc-alkaline compositions for these orthogneisses, whereas $\varepsilon_{\mathrm{Nd}(\mathrm{t})}$ values are largely variable, reaching the most negative values between -10.2 and -6.3 in the southern Epupa Complex (Kröner et al., 2010; Kleinhanns et al., 2013). Though unclear, the Epupa Complex together with the slightly older Kamanjab Inlier (ca. 1.86-1.83 Ga) of the Angolan Shield are interpreted as the result of continental arc magmatism (Kröner et al., 2010, 2015; Kleinhanns et al., 2013; McCourt et al., 2013).

Correlations between the Dom Feliciano and Kaoko Belt are well-established, mostly based on similarities in the Neoproterozoic geological record (Fig. 15; Goscombe and Gray, 2007, 2008; Oyhantçabal et al., 2009; Basei et al., 2011; Konopásek et al., 2014, 2016, 2017, 2018; Oriolo et al., 2016a, 2016c). Additionally, the Nico Pérez Terrane represents a basement inlier of the Dom Feliciano Belt and has an African affinity, probably linked to the southwestern Congo Craton (Oriolo et al., 2016a; Oyhantçabal et al., 2018a). Hence, a common late Paleoproterozoic evolution of the Nico Pérez Terrane, basement inliers of the Kaoko Belt and the Angolan Shield seem plausible, possibly related to the evolution of a 
continental magmatic arc. Kröner et al. (2010) indicated ductile deformation and metamorphism contemporaneous with the emplacement of most intrusions of the Epupa Complex, culminating with crustal anatexis and post-kinematic granites at ca. 1.76-1.75 Ga. Within this framework, intrusive rocks of the Illescas granite and the Campanero Unit might be comparable to these late anatectic melts, thus recording a similar post-orogenic scenario. Though the nature of this late event is uncertain, the accretion of an island arc or comparable juvenile magmatic complexes along a convergent continental margin would satisfactorily explain most data. If so, Lu-Hf and Sm-Nd data suggest that the Nico Pérez Terrane and the southern Epupa Complex might represent relics of the former continental margin.

In contrast, Statherian magmatism of the Nico Pérez Terrane was correlated with the Florida mafic dyke swarm of the Piedra Alta Terrane (i.e., Río de la Plata Craton, Fig. 1), which yields a U-Pb ID-TIMS baddeleyite age of $1790 \pm 5 \mathrm{Ma}$ (Halls et al., 2001), suggesting a common evolution of both areas (Santos et al., 2019). However, the Florida dyke swarm shows a tholeiitic geochemical signature linked to an extensional setting (Bossi et al., 1993; Teixeira et al., 1999, 2013), showing a clear contrast with coeval rocks of the Nico Pérez Terrane of Uruguay and southern Brazil. Thus, these differences further support the allochthony of the Nico Pérez Terrane with regard to the Río de la Plata Craton (Oyhantçabal et al., 2011b, 2018a; Oriolo et al., 2015, 2016a, 2016b).

On the other hand, the Capivarita anorthosite, exposed in the Brazilian counterpart of the Nico Pérez Terrane, yields a U-Pb LA-ICP-MS zircon age of $1573 \pm 21 \mathrm{Ma}$, with variable $\varepsilon_{\mathrm{Hf}(\mathrm{t})}$ values between -5.64 and +6.42 that reflect both addition of juvenile material and crustal reworking (Chemale et al., 2011). In this region, Camozzato et al. $(2013,2017)$ obtained a $\mathrm{U}-\mathrm{Pb}$ LA-ICP-MS zircon age of $1567 \pm 21 \mathrm{Ma}$ for the Tupi Silveira amphibolite. Similarly, amphibolitic xenoliths of Neoproterozoic intrusions exposed in the northern Dom Feliciano Belt yield a U-Pb SHRIMP zircon age of $1563 \pm 25 \mathrm{Ma}$ and a dominantly juvenile Lu-Hf signature recorded by positive $\varepsilon_{H f(t)}$ values (Basei et al., 2013). In the Apiaí Domain of the Ribeira Belt, the Betara Formation hosts metabasic rocks with U-Pb TIMS zircon multigrain ages of $1476 \pm 10$ and $1489 \pm 11 \mathrm{Ma}$ (Siga Jr. et al., 2011a), whereas the Votuverava Group of the Ribeira Belt exhibits mafic magmatism yielding U-Pb SHRIMP zircon ages of $1484 \pm$ 16 and $1488 \pm 4$ Ma (Siga Jr. et al., 2011b; Campanha et al., 2015). Metabasic rocks of the 
Apiaí Domain are thus coeval with metagabbros of the Nico Pérez Terrane of Uruguay, and also present a similar geochemical and $\mathrm{Sm}-\mathrm{Nd}$ fingerprint, suggesting a common origin in an extensional setting (Siga Jr. et al., 2011a, 2011b; Campanha et al., 2015). Further north, in the São Francisco Craton, U-Pb LA-ICP-MS zircon data indicate an age of ca. 1.43 Ga for volcaniclastic rocks of the Upper Tombador Formation in the Espinhaço Supergroup, interpreted as the result of continental rifting sedimentation and volcanism (Guadagnin et al., 2015a, 2015b), whereas U-Pb baddeleyite ages of $1506.7 \pm 6.9$ and 1501.0 $\pm 9.1 \mathrm{Ma}$ were reported for the Curaçá and Chapada Diamantina mafic dykes (Silveira et al., 2013). The latter are only slightly older than the Zanja del Tigre Mesoproterozoic metagabbros and show a similar geochemical fingerprint.

Together with the late Paleoproterozoic intrusions, Mesoproterozoic granitic gneisses yielding SHRIMP and conventional U-Pb TIMS multigrain zircon ages of ca. 1.55 and 1.45 Ga were identified by Seth et al. (1998), Kröner et al. (2004) and Luft et al. (2011) in the Kaoko Belt. In the southwestern Angolan Shield, several undeformed intrusions intruding the Epupa Complex yielded U-Pb SHRIMP zircon crystallization ages of 1.53-1.42 Ga (Kröner and Rojas-Agramonte, 2017) and are coeval with UHT metamorphism of Paleoproterozoic gneisses (Seth et al., 2003; Brandt et al., 2003). Likewise, a $1502 \pm 5$ Ma $\mathrm{U}-\mathrm{Pb}$ TIMS baddeleyite age was obtained for the Humpata dolerite sill, which corresponds to widespread intraplate magmatism in the southwestern Angolan Shield (Ernst et al., 2013). Early Ectasian intrusions are present as well (Kröner and Rojas-Agramonte, 2017), being contemporaneous with the ca. 1.38-1.36 Ga Kunene Anorthosite Complex (Drüppel et al., 2007; McCourt et al., 2013), exposed immediately east.

In sum, several southwestern Gondwana regions, including the Nico Pérez Terrane, basement inliers of the Kaoko Belt and the Congo-São Francisco Craton, record several pulses of magmatism between ca. 1.56 and $1.36 \mathrm{Ga}$ (Fig. 15), which imply local addition of juvenile crust (Drüppel et al., 2007; Chemale et al., 2011; Basei et al., 2013). Geochemical and isotopic data, on the other hand, point to dominant extensional settings (Ernst et al., 2013; Guadagnin et al., 2015a, 2015b; Kröner and Rojas-Agramonte, 2017), probably linked to widespread continental rifting. Hence, both late Paleoproterozoic and early Mesoprotezoic intrusions represent two distinct magmatic events in southeastern South America, which, 
together with the Archean and Rhyacian record (Oriolo et al., 2016a; Oyhantçabal et al., 2018a), further support correlations between the Nico Pérez Terrane and the Angolan Shield.

Despite the lack of paleomagnetic data for the Nico Pérez Terrane, correlations with the Angolan Shield may provide some hints to reconstruct its paleogeography during the late Paleoproterozoic-Mesoproterozoic, which is so far unknown (e.g., Evans and Mitchell, 2011; Zhang et al., 2012; Pisarevsky et al., 2014). Paleomagnetic data of the Curaçá mafic dykes (Fig. 15; Salminen et al., 2016) and similarities in the Calymmian-early Ectasian magmatic record suggest that the Congo-São Francisco Craton was located at moderate latitudes in the southern hemisphere, in a marginal position within the Nuna supercontinent and relatively close to Siberia (e.g., Ernst et al., 2013; Pisarevsky et al., 2014; Pehrsson et al., 2016). Within this framework, the late Paleoproterozoic tectonomagmatic evolution of the Nico Pérez Terrane, basement inliers of the Kaoko Belt and the Angolan Shield might be related to orogenic events related to Nuna assembly, probably associated with an active margin along the western (present coordinates) Congo-São Francisco Craton (Evans and Mitchell, 2011; Pehrsson et al., 2016). Likewise, extension-related intraplate Calymmian magmatism of the Nico Pérez Terrane might be associated with Nuna break-up (Evans and Mitchell, 2011; Pisarevsky et al., 2014), similarly to key Mesoproterozoic intraplate magmatic events recorded in the Congo-São Francisco Craton and Siberia (Ernst et al., 2013), thus supporting a possible common evolution of all these blocks.

\section{Conclusions}

The U-Pb LA-ICP-MS zircon age of $1768 \pm 11$ Ma confirms the Statherian age for the Illescas rapakivi intrusion, being comparable within error with an age of the Campanero Unit felsic orthogneisses. Both Illescas and Campanero intrusions exhibit essentially granitic, meta- to peraluminous compositions. However, the Illescas granite show dominant shoshonitic and ferroan compositions, whereas high-K calc-alkaline and magnesian to ferroan compositions characterized orthogneisses of the Campanero Unit. Both units present comparable trace element patterns, with enrichment of LILE with respect to HFSE and marked negative anomalies of $\mathrm{Nb}$, Ta, $\mathrm{P}$ and Ti. Additionally, $\mathrm{Sm} / \mathrm{Yb}$ and $\mathrm{La}_{\mathrm{N}} / \mathrm{Yb}_{\mathrm{N}}$ ratios indicate that both suites were emplaced in a thickened crust. On the other hand, new Lu-Hf 
data of the Illescas granite together with available Sm-Nd data of the Campanero Unit point to dominant crustal reworking processes for this late Paleoproterozoic magmatism, implying recycling of older Archean and/or Paleoproterozoic crust of the Nico Pérez Terrane.

Geochemical, isotopic and geochronological data suggest a common origin for both the Illescas and Campanero magmatism, probably related to a post-collisional/post-orogenic setting. Coeval magmatism is also recorded by the Seival Metagranite (northern Nico Pérez Terrane, Brazil), basement inliers of the Ribeira and Kaoko Belts, and the Epupa Complex in the Angolan Shield (southwestern Congo Craton). Altogether, geochemical and isotopic data of all these units can be interpreted as the result of late Orosirian-early Statherian convergence along a continental margin, likely to be represented by the Nico Pérez Terrane and the southern Epupa Complex. Along this margin, not only reworked continental arc magmatism but also juvenile suites representing island arc and/or ocean island magmatism were recorded. The latter were probably accreted along the continental margin, triggering metamorphism and deformation mostly preserved in the African complexes. Within this framework, the Illescas and Campanero magmatism might be thus comparable with late anatectic melts of the Epupa Complex recorded at ca. 1.76-1.75 Ga, probably succeeding accretional tectonic events.

On the other hand, metagabbros of the Zanja del Tigre Complex present U-Pb LAICP-MS zircon ages of $1479 \pm 4$ and $1482 \pm 6$ Ma and tholeiitic gabbroic compositions. Trace element and REE patterns are comparable to those recorded by LIP-related mafic magmatism, such as low-Ti basalts and dolerites of the Paraná-Etendeka-Karoo province. In this sense, the most likely source might be a mixture of depleted asthenospheric and fertile subcontinental lithospheric mantle magmas, with lithospheric mantle fertilization resulting from Paleoproterozoic tectonomagmatic events.

The geochemical and isotopic signature of metagabbros suggests emplacement during lithospheric extension in a continental rifting setting. Comparable extensional magmatism and associated sedimentation is recorded between ca. 1.56 and $1.36 \mathrm{Ga}$ in other basement inliers of the Dom Feliciano and Ribeira Belts, the São Francisco Craton, basement remnants of the Kaoko Belt and the Angolan Shield. In contrast to Paleoproterozoic and Neoproterozoic events, the Calymmian-early Ectasian evolution of these southwestern 
Gondwanan regions is thus characterized by lithospheric extension, implying local addition of juvenile crust.

Together with similarities in Rhyacian and Archean tectonomagmatic processes, the late Paleoproterozoic-Mesoproterozoic record of the Nico Pérez Terrane allows tightening up correlations across the South Atlantic between South America and Africa prior to the Neoproterozoic. Based on similarities with coeval magmatism in the Angolan Shield and the Congo-São Francisco Craton, late Paleoproterozoic and Mesoproterozoic intrusions might be associated with major orogenic and rifting events related to Nuna assembly and break-up, respectively, indicating a common evolution of these blocks.

\section{Acknowledgements}

The authors want to thank Wilson Teixeira for the editorial work, and Jean-Paul Liégeois and an anonymous reviewer for their valuable comments, which helped to significantly improve the manuscript. Sebastián Oriolo thanks DAAD for a long-term $\mathrm{PhD}$ scholarship (A/12/75051). Jiří Konopásek acknowledges the grant support by the Czech Science Foundation (project 18-24281S). Jiří Sláma was supported by the RVO 67985831institutional support to the IG ASCR.

\section{References}

Alviola, R., Johanson, B.S., Rämö, O.T., Vaasjoki, M., 1999. The Proterozoic Ahvenisto rapakivi granite-massif-type anorthosite complex, southeastern Finland; petrography and UPb chronology. Precambrian Research 5, 89-107.

Basei, M.A.S., Frimmel, H.E., Nutman, A.P., Preciozzi, F., Jacob, J., 2005. A connection between the Neoproterozoic Dom Feliciano (Brazil/Uruguay) and Gariep (Namibia/South Africa) orogenic belts - evidence from a reconnaissance provenance study. Precambrian Research 139, 195-221.

Bardintzeff, J.-M., Liégeois, J.-P., Bonin, B., Bellon, H., Rasamimanana, G., 2010. Madagascar volcanic provinces linked to the Gondwana break-up: Geochemical and isotopic evidences for contrasting mantle sources. Gondwana Research 18, 295-314. 
Basei, M.A.S., Frimmel, H.E., Nutman, A.P., Preciozzi, F., 2008. West Gondwana amalgamation based on detrital zircon ages from Neoproterozoic Ribeira and Dom Feliciano belts of South America and comparison with coeval sequences from SW Africa, in: Pankhurst, R.J., Trouw, R.A.J., Brito Neves, B.B., de Wit, M.J. (Eds.), West Gondwana: PreCenozoic correlations across the South Atlantic region. Geological Society Special Publication, London, 294, pp. 239-256.

Basei, M.A.S., Peel, E., Sánchez Bettucci, L., Preciozzi, F., Nutman, A.P., 2011. The basement of the Punta del Este Terrane (Uruguay): an African Mesoproterozoic fragment at the eastern border of the South American Río de la Plata craton. International Journal of Earth Sciences 100, 289-304.

Basei, M.A.S., Frimmel, H.E., Campos Neto, M.C., Ganade de Araujo, C.E., Araujo de Castro, N., Passarelli, C.R., 2018. The tectonic history of the southern Adamastor Ocean based on a correlation of the Kaoko and Dom Feliciano belts, in: Siegesmund, S., Basei, M.A.S., Oyhantçabal, P., Oriolo, S. (Eds.), Geology of Southwest Gondwana. Regional Geology Reviews, Springer International Publishing AG, pp. 63-85.

Batchelor, R.A., Bowden, P., 1985. Petrogenetic interpretation of granitoid rock series using multicationic parameters. Chemical Geology 48, 43-55.

Blichert-Toft, J., Albarède, F., 1997. The Lu-Hf geochemistry of chondrites and the evolution of the mantle-crust system. Earth and Planetary Science Letters 148, 243-258.

Bossi, J., Campal, N., 1992. Magmatismo y tectónica transcurrente durante el Paleozoico inferior del Uruguay, in: Gutiérrez, J., Saavedra, J., Rábano, I. (Eds.), Paleozoico Inferior de Ibero-América. Universidad de Extremadura, Alicante, pp. 343-356.

Bossi, J., Campal, N., Civetta, L., Demarchi, G., Girardi, V.A.V., Mazzucchelli, M., Negrini, L., Rivalenti, G., Fragoso Cesar, A.R.S., Sinigoi, S., Teixeira, W., Piccirillo, E.M., Molesini, M., 1993. Early Proterozoic dike swarms from western Uruguay: geochemistry, Sr-Nd isotopes and petrogenesis. Chemical Geology 106, 263-277.

Boynton, W.V., 1984. Cosmochemistry of the rare earth elements: meteorite studies, in: Henderson, P. (Ed.), Rare Earth Element Geochemistry. Elsevier, Amsterdam, pp. 63-114.

Brandt, S., Klemd, R., Okrusch, M., 2003. Ultrahigh-temperature metamorphism and multistage garnet evolution of garnet-orthopyroxene granulites from the Proterozoic Epupa Complex, NW Namibia. Journal of Petrology 44, 1121-1144.

Campal, N., Schipilov, A., 1995. The Illescas bluish quartz rapakivi granite (Uruguay-South America): Some Geological Features. Symposium rapakivi granites and related rocks, Belen.

Campal, N., Schipilov, A., 1999. The eastern edge of the Río de la Plata Craton: A history of tangential collisions, in: Sinha, A.K. (Ed.), Basement Tectonics. Springer, Dordrecht, 13, pp. $33-48$. 
Campanha, G.A.C., Faleiros, F.M., Basei, M.A.S., Tassinari, C.C.G., Nutman, A.P., Vasconcelos, P.M., 2015. Geochemistry and age of mafic rocks from the Votuverava Group, southern Ribeira Belt, Brazil: Evidence for 1490 Ma oceanic back-arc magmatism. Precambrian Research 266, 530-550.

Chemale, F., Philipp, R.P., Dussin, I.A., Liquintinie Formoso, M.L., Kawashita, K., Losangela Berttotti, A., 2011. Lu-Hf and U-Pb age determination of Capivarita Anorthosite in the Dom Feliciano Belt, Brazil. Precambrian Research 186, 117-126.

Chiglino, L., Gaucher, C., Sial, A.N., Bossi, J., Ferreira, V.P., 2008. Chemostratigraphy of Mesoproterozoic carbonates in the Nico Pérez Terrane (Río de la Plata Craton). $33^{\circ}$ International Geological Congress, Oslo.

Chiglino, L., Gaucher, C., Sial, A.N., Bossi, J., Ferreira, V.P., Pimentel, M.M., 2010. Chemostratigraphy of Mesoproterozoic and Neoproterozoic carbonates of the Nico Pérez Terrane, Río de la Plata Craton, Uruguay. Precambrian Research 182, 313-336.

Cingolani, C.A., 2011. The tandilia system of Argentina as a southern extension of the Río de la Plata craton: an overview. International Journal of Earth Sciences 100, 221-242.

Costa, M.A.C., Sousa, M.Z.A., Dall'Agnol, R., Scandolara, J.E., Salina Ruiz, A., 2016. Geochemistry and geochronology of the rapakivi granites and associated rocks in the midwest portion of the Serra da Providência composite batholith, SW of Amazonian craton, Rondônia, Brazil. Journal of South American Earth Sciences 69, 194-212.

Cury, L.F., Kaulfuss, G.A., Siga Jr., O., Basei,M.A.S., Harara, O.M.M., Sato, K., 2002. Idades U-Pb (zircões) de 1,75 Ga em granitóides alcalinos deformados dos núcleos Betara e Tigre: Evidências de regimes extensionais do Estateriano na Faixa Apiaí. Geologia USP Série Científica 2, 95-108.

Drüppel, K., Littmann, S., Romer, R.L., Okrusch, M., 2007. Petrology and isotope geochemistry of the Mesoproterozoic anorthosite and related rocks of the Kunene Intrusive Complex, NW Namibia. Precambrian Research 156, 1-31.

Eby, G.N., 1992. Chemical subdivision of the A-type granitoids: Petrogenetic and tectonic implications. Geology 20, 641-644.

Elhlou, S., Belousova, E., Griffin, W.L., Pearson, N.J., O’Reilly, S.Y., 2006. Trace element and isotopic composition of GJ-red zircon standard by laser ablation. Geochimica et Cosmochimica Acta 70, A158.

Ernst, R.E., Pereira, E., Hamilton, M.A., Pisarevsky, S.A., Rodriques, J., Tassinari, C.C.G., Teixeira, W., Van-Dunem, V., 2013. Mesoproterozoic intraplate magmatic “'barcode” record of the Angola portion of the Congo Craton: newly dated magmatic events at 1505 and 1110 $\mathrm{Ma}$ and implications for Nuna (Columbia) supercontinent reconstructions. Precambrian Research 230, 103-118. 
Eyal, M., Litvinovsky, B., Jahn, B.M., Zanvilevich, A., Katzir, Y., 2010. Origin and evolution of post-collisional magmatism: Coeval Neoproterozoic calc-alkaline and alkaline suites of the Sinai Peninsula. Chemical Geology 269, 153-179.

Evans, D.A., Mitchell, R.N., 2011. Assembly and breakup of the core of PaleoproterozoicMesoproterozoic supercontinent Nuna. Geology 39, 443-446.

Fisher, C.M., Vervoort, J.D., Hanchar, J.M., 2014. Guidelines for reporting zircon Hf isotopic data by LA-MC-ICPMS and potential pitfalls in the interpretation of these data. Chemical Geology 363, 125-133.

Frei, R., Polat, A., 2013. Chromium isotope fractionation during oxidative weathering Implications from the study of a Paleoproterozoic (ca. 1.9 Ga) paleosol, Schreiber Beach, Ontario, Canada. Precambrian Research 224, 434-453.

Frost, B.R., Calving, G.B., Collins, W.J.R, Arculus, R.J., Ellis, D.J., Frost, C.D., 2001. A geochemical classification for granitic rocks. Journal of Petrology 42, 2033-2048.

Gaucher, C., Blanco, G. 2014. Batolito de Illescas, in: Bossi, J., Gaucher, C. (Eds.), Geología del Uruguay, Predevónico. Universidad de la República, Montevideo, pp. 209-214.

Gaucher, C., Frei, R., Chemale Jr., F., Frei, D., Bossi, J., Martínez, G., Chiglino, L., Cernuschi, F., 2011. Mesoproterozoic evolution of the Río de la Plata Craton in Uruguay: at the heart of Rodinia? International Journal of Earth Sciences 100, 273-288.

Gaucher, C., Bossi, J., Martínez, G., Chiglino, L., Frei, R., Sial, A.N., 2014. Grupo Parque UTE, in: Bossi, J., Gaucher, C. (Eds.), Geología del Uruguay, Predevónico. Universidad de la República, Montevideo, pp. 215-232.

Goldstein, S.L., O’Nions, R.K., Hamilton, P.J., 1984. A Sm-Nd isotopic study of atmospheric dusts and particulates from major river systems. Earth and Planetary Science Letters 70, 221 236.

Goscombe, B., Gray, D.R., 2007. The Coastal Terrane of the Kaoko Belt, Namibia: outboard arc-terrane and tectonic significance. Precambrian Research 155, 139-158.

Goscombe, B., Gray, D.R., 2008. Structure and strain variation at mid-crustal levels in a transpressional orogen: a review of Kaoko Belt structure and the character of West Gondwana amalgamation and dispersal. Gondwana Research 13, 45-85.

Griffin, W.L., Wang, X., Jackson, S.E., Pearson, N.J., O’Reilly, S.Y., Xu, X., Zhou, X., 2002. Zircon chemistry and magma mixing, SE China: In-situ analysis of Hf isotopes, Tonglu and Pingtan igneous complexes. Lithos 61, 237-269.

Guadagnin, F., Chemale Jr., F., Magalhães, A.J.C., Santana, A., Dussin, I., Takehara, L., 2015a. Age constraints on crystal-tuff from the Espinhaço Supergroup - Insight into the Paleoproterozoic to Mesoproterozoic intracratonic basin cycles of the Congo-São Francisco Craton. Gondwana Research 27, 363-376. 
Guadagnin, F., Chemale Jr., F., Magalhães, A.J.C., Alessandretti, L., Bállico, B., Jelinek, A.R., 2015b. Sedimentary petrology and detrital zircon U-Pb and Lu-Hf constraints of Mesoproterozoic intracratonic sequences in the Espinhaço Supergroup: Implications for the Archean and Proterozoic evolution of the São Francisco Craton. Precambrian Research 266, 227-245.

Halls, H.C., Campal, N., Davis, D.W., Bossi, J., 2001. Magnetic studies and U-Pb geochronology of the Uruguayan dyke swarm, Rio de la Plata craton, Uruguay: paleomagnetic and economic implications. Journal of South American Earth Sciences 14, 349-361.

Heinonen, A., Andersen, T., Rämö, O.T., 2010. Re-evaluation of rapakivi petrogenesis: Source constraints from the Hf isotope composition of zircon in the rapakivi granites and associated mafic rocks of southern Finland. Journal of Petrology 51, 1687-1709.

Heinonen, A., Andersen, T., Rämö, O.T., Whitehouse, M., 2014. The source of Proterozoic anorthosite and rapakivi granite magmatism: evidence from combined in situ Hf-O isotopes of zircon in the Ahvenisto complex, southeastern Finland. Journal of the Geological Society $172,103-112$.

Hu, F., Ducea, M.N., Liu, S., Chapman, J.B., 2017. Quantifying crustal thickness in continental collisional belts: Global perspective and a geologic application. Scientific Reports 7, 7058.

Hueck, M., Oriolo, S., Dunkl, I., Wemmer, K., Oyhantçabal, P., Schanofski, M., Basei, M.A.S., Siegesmund, S., 2017. Phanerozoic low-temperature evolution of the Uruguayan Shield along the South American passive margin. Journal of the Geological Society 174, 609626.

Hueck, M., Oyhantçabal, P., Philipp, R.P., Basei, M.A.S., Siegesmund, S.,2018. The Dom Feliciano Belt in southern Brazil and Uruguay, in: Siegesmund, S., Basei, M.A.S., Oyhantçabal, P., Oriolo, S. (Eds.), Geology of Southwest Gondwana. Regional Geology Reviews, Springer International Publishing AG, pp. 267-302.

Irvine, T.N., Baragar, W.R.A., 1971. A Guide to the Chemical Classification of the Common Volcanic Rocks. Canadian Journal of Earth Sciences 8, 523-548.

Jackson, S.E., Pearson, N.J., Griffin, W.L., Belousova, E.A. 2004. The application of laser ablation-inductively coupled plasma-mass spectrometry to in situ U-Pb zircon geochronology. Chemical Geology 211, 47-69.

Janoušek, V., Farrow, C.M., Erban, V., 2006. Interpretation of whole-rock geochemical data in igneous geochemistry: introducing Geochemical Data Toolkit (GCDkit). Journal of Petrology 47, 1255-1259.

Janoušek, V., Moyen, J.-F., Martin, H., Erban, V., Farrow, C., 2016. Geochemical modelling of igneous processes - Principles and recipes in R language. Springer, Berlin Heideberg. 
Jelsma, H.A., McCourt, S., Perritt, S.H., Armstrong, R.A., 2018. The geology and evolution of the Angolan Shield, Congo Craton, in: Siegesmund, S., Basei, M.A.S., Oyhantçabal, P., Oriolo, S. (Eds.), Geology of Southwest Gondwana. Regional Geology Reviews, Springer International Publishing AG, pp. 217-239.

Kleinhanns, I.C., Fullgraf, T., Wilsky, F., Nolte, N., Fliegel, D., Klemd, R., Hansen, B.T., 2013. U-Pb zircon ages and (isotope) geochemical signatures of the Kamanjab Inlier (NW Namibia): constraints on Palaeoproterozoic crustal evolution along the southern Congo craton,in: Roberts, N.M.W., van Kranendonk, M., Parman, S., Shirey, S., Clift, P.D. (Eds.), Continent formation through time. Geological Society Special Publication, London, 389, pp. 165-195.

Konopásek, J., Košler, J., Sláma, J., Janoušek, V., 2014. Timing and sources of precollisional Neoproterozoic sedimentation along the SW margin of the Congo Craton (Kaoko Belt, NW Namibia). Gondwana Research 26, 386-401.

Konopásek, J., Sláma, J., Košler, J., 2016. Linking the basement geology along the AfricaSouth America coasts in the South Atlantic. Precambrian Research 280, 221-230.

Konopásek, J., Hoffmann, K.-H., Sláma, J., Košler, J., 2017. The onset of flysch sedimentation in the Kaoko Belt (NW Namibia) - Implications for the pre-collisional evolution of the Kaoko-Dom Feliciano-Gariep orogen. Precambrian Research 298, 220-234.

Konopásek, J., Janoušek, V., Oyhantçabal, P., Sláma, J., Ulrich, S., 2018. Did the circumRodinia subduction trigger the Neoproterozoic rifting along the Congo-Kalahari Craton margin? International Journal of Earth Sciences 107, 1859-1894.

Kröner, A., Rojas-Agramonte, Y., 2017. Mesoproterozoic (Grenville-age) granitoids and supracrustal rocks in Kaokoland, northwestern Namibia. Precambrian Research 298, 572592.

Kröner, S., Konopásek, J., Kröner, A., Passchier, C.W., Poller, U., Wingate, M.W.D., Hofmann, K.H., 2004. U-Pb and Pb-Pb zircon ages for metamorphic rocks in the Kaoko Belt of Northwestern Namibia: a Palaeo- to Mesoproterozoic basement reworked during the PanAfrican orogeny. South African Journal of Geology 107, 455-476.

Kröner, A., Rojas-Agramonte, Y., Hegner, E., Hoffmann, K.-H., Wingate, M.T.D., 2010. SHRIMP zircon dating and $\mathrm{Nd}$ isotopic systematics of Palaeoproterozoic migmatitic orthogneisses in the Epupa Metamorphic Complex of northwestern Namibia. Precambrian Research 183, 50-69.

Kröner, A., Rojas-Agramonte, Y., Wong, J., Wilde, S.A., 2015. Zircon reconnaissance dating of Proterozoic gneisses along the Kunene River of northwestern Namibia. Tectonophysics $662,125-139$.

Lan, T.-G., Fan, H.-R., Santosh, M., Hu, F.-F., Yang, K.-F., Yang, Y.-H., Liu, Y., 2012. Early Jurassic high-K calc-alkaline and shoshonitic rocks from the Tongshi intrusive complex, 
eastern North China Craton: Implication for crust-mantle interaction and post-collisional magmatism. Lithos 140-141, 183-199.

Lara, P., Oyhantçabal, P., Dadd, K., 2017. Post-collisional, Late Neoproterozoic, high-Ba-Sr granitic magmatism from the Dom Feliciano Belt and its cratonic foreland, Uruguay: Petrography, geochemistry, geochronology, and tectonic implications. Lithos 277, 178-198.

Liégeois, J.-P., Navez, J., Hertogen, J., Black, R., 1998. Contrasting origin of post-collisional high-K calc-alkaline and shoshonitic versus alkaline and peralkaline granitoids. The use of sliding normalization. Lithos 45, 1-28.

Ludwig, K.R., 2008. Isoplot 3.70. A geochronological toolkit for Microsoft Excel, Berkeley Geochronology Center Special Publications, Berkeley.

Luft Jr., J.L., Chemale Jr., F., Armstrong, R., 2011. Evidence of 1.8- to 1.7-Ga collisional arc in the Kaoko Belt, NW Namibia. International Journal of Earth Sciences 100, 305-321.

Mallmann, G., Chemale Jr., F., Ávila, J.N., Kawashita, K., Armstrong, R.A., 2007. Isotope geochemistry and geochronology of the Nico Pérez Terrane, Rio de la Plata Craton, Uruguay. Gondwana Research 12, 489-508.

Mamani, M., Wörner, G., Sempere, T., 2010. Geochemical variations in igneous rocks of the Central Andean orocline $\left(13^{\circ} \mathrm{S}\right.$ to $\left.18^{\circ} \mathrm{S}\right)$ : Tracing crustal thickening and magma generation through time and space. Geological Society of America Bulletin 122, 162-182.

Masquelin, H., Silva Lara, H., Sánchez Bettucci, L., Núñez Demarco, P., Pascual, S., Muzio, R., Peel, E., Scaglia, F., 2017. Lithologies, structure and basement-cover relationships in the schist belt of the Dom Feliciano Belt in Uruguay. Brazilian Journal of Geology 47, 21-42.

McCourt, S., Armstrong, R.A., Jelsma, H., Mapeo, R.B.M., 2013. New U-Pb SHRIMP ages from the Lubango region, SW Angola: insights into the Palaeoproterozoic evolution of the Angolan Shield, southern Congo Craton, Africa. Journal of the Geological Society 170, 353363.

McDonough, W.F., Sun, S.-S., 1995. Composition of the Earth. Chemical Geology 120, 223253.

Middlemost, E.A.K., 1994. Naming materials in magma/igneous rock system. Earth Science Reviews 37, 215-224.

Moore, M., Davis, D.W., Robb, L.J., Jackson, M.C., Grobler, D.F., 1993. Archean rapakivi granite-anorthosite-rhyolite complex in the Witwatersrand basin hinterland, southern Africa. Geology 21, 1031-1034.

Ohta, T., Arai, H., 2007. Statistical empirical index of chemical weathering in igneous rocks: A new tool for evaluating the degree of weathering. Chemical Geology 240, 280-297. 
Oriolo, S., Oyhantçabal, P., Heidelbach, F., Wemmer, K., Siegesmund, S., 2015. Structural evolution of the Sarandí del Yí Shear Zone, Uruguay: kinematics, deformation conditions and tectonic significance. International Journal of Earth Sciences 104, 1759-1777.

Oriolo, S., Oyhantçabal, P., Basei, M.A.S., Wemmer, K., Siegesmund, S., 2016a. The Nico Pérez Terrane (Uruguay): from Archean crustal growth and connections with the Congo Craton to late Neoproterozoic accretion to the Río de la Plata Craton. Precambrian Research $280,147-160$.

Oriolo, S., Oyhantçabal, P., Wemmer, K., Basei, M.A.S., Benowitz, J., Pfänder, J., Hannich, F., Siegesmund, S., 2016b. Timing of deformation in the Sarandí del Yí Shear Zone, Uruguay: implications for the amalgamation of Western Gondwana during the Neoproterozoic Brasiliano-Pan-African Orogeny. Tectonics 35, 754-771.

Oriolo, S., Oyhantçabal, P., Wemmer, K., Heidelbach, F., Pfänder, J., Basei, M.A.S., Hueck, M., Hannich, F., Sperner, B., Siegesmund, S., 2016c. Shear zone evolution and timing of deformation in the Neoproterozoic transpressional Dom Feliciano belt, Uruguay. Journal of Structural Geology 92, 59-78.

Oriolo, S., Oyhantçabal, P., Wemmer, K., Siegesmund, S., 2017. Contemporaneous assembly of Western Gondwana and final Rodinia break-up: Implications for the supercontinent cycle. Geoscience Frontiers 8, 1431-1445.

Oyhantçabal, P. 2005. The Sierra Ballena shear zone: kinematics, timing and its significance for the geotectonic evolution of southeast Uruguay (Ph.D. thesis). Georg-August-Universität Göttingen, Germany.

Oyhantçabal, P., Sánchez Bettucci, L., Pecoits, E., Aubet, N., Peel, E., Preciozzi, F., Basei, M.A.S., 2005. Nueva propuesta estratigráfica para las supracorticales del Cinturón Dom Feliciano (Proterozoico Uruguay). $12^{\circ}$ Congreso Latinoamericano de Geología, Quito.

Oyhantçabal, P., Siegesmund, S., Wemmer, K., Frei, R., Layer, P., 2007. Postcollisional transition from calc-alkaline to alkaline magmatism during transcurrent deformation in the southernmost Dom Feliciano Belt (Braziliano-Pan-African, Uruguay). Lithos 98, 141-159.

Oyhantçabal, P., Siegesmund, S., Wemmer, K., Presnyakov, S., Layer, P., 2009. Geochronological constraints on the evolution of the southern Dom Feliciano Belt (Uruguay). Journal of the Geological Society of London 166, 1075-1084.

Oyhantçabal, P., Siegesmund, S., Wemmer, K., Passchier, C.W., 2011a. The transpressional connection between Dom Feliciano and Kaoko Belts at 580-550 Ma. International Journal of Earth Sciences 100, 379-390.

Oyhantçabal, P., Siegesmund, S., Wemmer, K., 2011b. The Río de la Plata Craton: a review of units, boundaries, ages and isotopic signature. International Journal of Earth Sciences 100, 201-220. 
Oyhantçabal, P., Wegner-Eimer, M., Wemmer, K., Schulz, B., Frei, R., Siegesmund, S., 2012. Paleo- and Neoproterozoic magmatic and tectonometamorphic evolution of the Isla Cristalina de Rivera (Nico Pérez Terrane, Uruguay). International Journal of Earth Sciences 101, 1745-1762.

Oyhantçabal, P., Oriolo, S., Philipp, R., Siegesmund, S., Wemmer, K., 2018a. The Nico Pérez Terrane of Uruguay and southeastern Brazil, in: Siegesmund, S., Basei, M.A.S., Oyhantçabal, P., Oriolo, S. (Eds.), Geology of Southwest Gondwana. Regional Geology Reviews, Springer International Publishing AG, pp. 161-188.

Oyhantçabal, P., Cingolani, C., Wemmer, K., Siegesmund, S., 2018b. The Río de la Plata Craton of Argentina and Uruguay, in: Siegesmund, S., Basei, M.A.S., Oyhantçabal, P., Oriolo, S. (Eds.), Geology of Southwest Gondwana. Regional Geology Reviews, Springer International Publishing AG, pp. 89-105.

Paton, C., Woodhead, J.D., Hellstrom, J.C., Hergt, J.M., Greig, A., Maas, R., 2010. Improved laser ablation $\mathrm{U}-\mathrm{Pb}$ zircon geochronology through robust downhole fractionation correction. Geochemistry, Geophysics, Geosystems 11, Q0AA06.

Pearce, J.A., 2008. Geochemical fingerprinting of oceanic basalts with applications to ophiolite classification and the search for Archean oceanic crust. Lithos 100, 14-48.

Pearce, J.A., Stern, R.J., 2006. Origin of back-arc basin magmas: Trace element and isotope perspectives. Geophysical Monograph Series 166, 63-86.

Pearce, J.A., Stern, R.J., Bloomer, S.H., Fryer, P., 2005. Geochemical mapping of the Mariana arc-basin system: Implications for the nature and distribution of subduction components. Geochemistry, Geophysics, Geosystems, doi: 10.1029/2004GC000895

Peate, D.W., Hawkesworth, C.J., 1996. Lithospheric to asthenospheric transition in Low-Ti flood basalts from southern Paraná, Brazil. Chemical Geology 127, 1-24.

Peccerillo, A., Taylor, S.R., 1976. Geochemistry of Eocene calc-alkaline volcanic rocks from the Kastamonu area, Northern Turkey. Contributions to Mineralogy and Petrology 58, 6381.

Pehrsson, S.J., Eglington, B.M., Evans, D.A.D., Huston, D., Reddy, S.M., 2016. Metallogeny and its link to orogenic style during the Nuna supercontinent cycle, in: Li, Z.X., Evans, D.A.D., Murphy, J.B. (Eds.), Supercontinent cycles through Earth history. Geological Society Special Publication, London, 424, pp. 83-94.

Peng, M., Wu, Y., Gao, S., Zhang, H., Wang, J., Liu, X., Gong, H., Zhou, L., Hu, Z., Liu, Y., Yuan, H., 2012. Geochemistry, zircon U-Pb age and Hf isotope compositions of Paleoproterozoic aluminous A-type granites from the Kongling terrain, Yangtze Block: Constraints on petrogenesis and geologic implications. Gondwana Research 22, 140-151.

Petrus, J.A., Kamber, B.S., 2012. VizualAge: a novel approach to Laser Ablation ICP-MS $\mathrm{U}-\mathrm{Pb}$ geochronology data reduction. Geostandards and Geoanalytical Research 36, 247-270. 
Pisarevsky, S.A., Elming, S.-Å., Pesonen, L.J., Li., Z.-X., 2014. Mesoproterozoic paleogeography: Supercontinent and beyond. Precambrian Research 244, 207-225.

Poiré, D.G., González, P.D., Canalicchio, J.M., García Repetto, F., 2003. Litoestratigrafía y estromatolitos de la sucesión sedimentaria Precámbrica de la cantera Mina Verdún, Minas, Uruguay. Revista de la Sociedad Uruguaya de Geología, Publicación Especial 1, 108-123.

Poiré, D.G., González, P.D., Canalicchio, J.M., García Repetto, F., Canessa, N.D., 2005. Estratigrafía del Grupo Mina Verdún, Proterozoico de Minas, Uruguay. Latin American Journal of Sedimentology and Basin Analysis 12,125-143.

Prazeres Filho, H.J., 2000. Litogeoquímica, geocronologia (U-Pb) e geologia isotópica dos complexos graníticos Cunhaporanga e Três Córregos, Estado do Paraná. M.Sc. Thesis, Universidade de São Paulo.

Profeta, L., Ducea, M.N., Chapman, J.B., Paterson, S.R., Henriquez Gonzales, S.M., Kirsch, M., Petrescu, L., DeCelles, P.G., 2015. Quantifying crustal thickness over time in magmatic arcs. Scientific Reports 5, 17786.

Rämö, O.T., Haapala, I., 1995. One hundred years of Rapakivi Granite. Mineralogy and Petrology 52, 129-185.

Rossini, C.A., Legrand, J.M., 2003. Eventos tecto-metamórficos del Grupo Carapé: un modelo para su evolución neoproterozoica. Publicación Especial de la Revista de la Sociedad Uruguaya de Geología 1, 49-67.

Salminen, J.M., Evans, D.A.D., Trindade, R.I.F., Oliveira, E.P., Piispa, E.J., Smirnov, A.V., 2016. Paleogeography of the Congo/São Francisco craton at $1.5 \mathrm{Ga}$ : Expanding the core of Nuna supercontinent. Precambrian Research 286, 195-212.

Sánchez Bettucci, L., Ramos, V.A., 1999. Aspectos geológicos de las rocas metavolcánicas y metasedimentarias del Grupo Lavalleja, sudeste de Uruguay. Revista Brasileira de Geociéncias 29, 557-570.

Sánchez Bettucci, L., Cosarinsky, M., Ramos, V.A., 2001. Tectonic setting of the Late Proterozoic Lavalleja Group (Dom Feliciano Belt), Uruguay. Gondwana Research 4, 395407.

Santos, J.O.S., Hartmann, L.A., Bossi, J., Campal, N., Schipilov, A., Piñeyro, D., McNaughton, N.J., 2003. Duration of the Trans-Amazonian cycle and its correlation within South America based on U-Pb SHRIMP geochronology of the La Plata Craton, Uruguay. International Geological Review 45, 27-48.

Santos, J.O.S., Chernicoff, C.J., Zappettini, E.O., McNaughton, N.J., Hartmann, L.A., 2019. Large geographic and temporal extensions of the Río de la Plata Craton, South America, and its metacratonic eastern margin. International Geology Review 61, 56-85.

Scandolara, J.E., Fuck, R.A., Dall'Agnol, R., Dantas, E.L., 2013. Geochemistry and origin of the early Mesoproterozoic mangerite-charnockite-rapakivi granite association of the Serra 
da Providência suite and associated gabbros, central-eastern Rondônia, SW Amazonian Craton, Brazil. Journal of South American Earth Sciences 45, 166-193.

Schmitt, R., de Araujo Fragoso, R., Collins, A.S., 2018. Suturing Gondwana in the Cambrian: The orogenic events of the final amalgamation, in: Siegesmund, S., Basei, M.A.S., Oyhantçabal, P., Oriolo, S. (Eds.), Geology of Southwest Gondwana. Regional Geology Reviews, Springer International Publishing AG, pp. 411-432.

Seth, B., Kröner, A., Mezger, K., Nemchin, A.A., Pidgeon, R.T., Okrusch, M., 1998. Archean to Neoproterozoic magmatic events in the Kaoko Belt of NW Namibia and their geodynamic significance. Precambrian Research 92, 341-363.

Shand, S.J., 1943. Eruptive rocks. Their genesis, composition, classification, and their relation to ore-deposits with a chapter on meteorite. John Wiley \& Sons, New York.

Siga Jr., O., Cury, L.F., McReath, I., de Almeida Leite Ribeiro, L.M., Sato, K., Basei, M.A.S., Passarelli, C.R., 2011a. Geology and geochronology of the Betare region in southsoutheastern Brazil: Evidence for possible Statherian (1.80-1.75 Ga) and Calymmian (1.50$1.45 \mathrm{Ga}$ ) extension events. Gondwana Research 19, 260-274.

Siga Jr., O., Basei, M.A.S., Sato, K., Passarelli, C.R., Nutman, A., McReath, I., dos Prazeres Filho, H.J., 2011b. Calymmian (1.50-1.45 Ga) magmatic records in Votuverava and Perau sequences, south-southeastern Brazil: Zircon ages and $\mathrm{Nd}-\mathrm{Sr}$ isotopic geochemistry. Journal of South American Earth Sciences 32, 301-308.

Silveira, E.M., Söderlund, U., Oliveira, E.P., Ernst, R.E., Menezes Leal, A.B., 2013. First precise $\mathrm{U}-\mathrm{Pb}$ baddeleyite ages of $1500 \mathrm{Ma}$ mafic dykes from the São Francisco Craton, Brazil, and tectonic implications. Lithos 174, 144-156.

Sláma, J., Košler, J., Condon, D.J., Crowley, J.L., Gerdes, A., Hanchar, J.M., Horstwood, M.S.A., Morris, G.A., Nasdala, L., Norberg, N., Schaltegger, U., Schoene, B., Tubrett, M.N., Whitehouse, M.J., 2008. Plešovice zircon - a new natural reference material for U-Pb and Hf isotopic microanalysis. Chemical Geology 249, 1-35.

Söderlund, U., Patchett, P.J., Vervoort, J.D., Isachsen, C.E., 2004. The ${ }^{176} \mathrm{Lu}$ decay constant determined by Lu-Hf and U-Pb isotope systematics of Precambrian mafic intrusions. Earth and Planetary Science Letters 219, 311-324.

Spoturno, J., Oyhantçabal, P., Faraone, M., 2017. Mapa geológico del Departamento de Lavalleja, escala 1:100000. Facultad de Ciencias-DINAMIGE.

Stacey, J.S., Kramers, J.D., 1975. Approximation of terrestrial lead isotope evolution by a two-stage model. Earth and Planetary Science Letters 26, 207-221.

Sun, S.S., McDonough, W.F., 1989. Chemical and isotopic systematics of oceanic basalts; implications for mantle composition and processes, in: Magmatism in the ocean basins. Saunders, A.D., Norry, M.J. (Eds.), Geological Society Special Publication, London, 42, pp. 313-345. 
Tanaka, T., Togashi, S., Kamioka, H., Amakawa, H., Kagami, H., Hamamoto, T., Yuhara, M., Orihashi, Y., Yoneda, S., Shimizu, H., Kunimaru, T., Takahashi, K., Yanagi, T., Nakano, T., Fujimaki, H., Shinjo, R., Asahara, Y., Tanimizu, M., Dragusanu G., 2000. JNdi1: a neodymium isotope reference in consistency with LaJolla neodymium. Chemical Geology $168,279-281$.

Teixeira, W., Renne, P.R., Bossi, J., Campal, N., D’Agrella Filho, M.S., 1999. ${ }^{40} \mathrm{Ar}-{ }^{39} \mathrm{Ar}$ and $\mathrm{Rb}-\mathrm{Sr}$ geochronology of the Uruguayan dike swarm, Rio de la Plata Craton and implications for Proterozoic intraplate activity in western Gondwana. Precambrian Research 93, 153-180.

Teixeira, W., D’Agrella Filho, M.S., Hamilton, M., Ernst, R.E., Girardi, V.A.V., Mazzuchelli, M., Bethencourt, J.S., 2013. U-Pb (ID-TIMS) baddeleyite ages and paleomagnetism of 1.79 and $1.59 \mathrm{Ga}$ tholeiitic dyke swarms, and position of the Rio de la Plata Craton within the Columbia supercontinent. Lithos 174, 157-174.

Trumbull, R.B., Reid, D.L., de Beer, C., van Acken, D., Romer, R.L., 2007. Magmatism and continental breakup at the west margin of southern Africa: A geochemical comparison of dolerite dikes from northwestern Namibia and the Western Cape. South African Journal of Geology 110, 477-502.

Vervoort, J.D, Blichert-Toft, J., 1999. Evolution of the depleted mantle: Hf isotope evidence from juvenile rocks through time. Geochimica et Cosmochimica Acta 63, 533-556.

Ware, B., Jourdan, F., Tohver, E., Fernandes, K.G., Chiaradia, M., 2018. Primary hydrous minerals from the Karoo LIP magmas: Evidence for a hydrated source component. Earth and Planetary Science Letters 503, 181-193.

Wiedenbeck, M., Alle, P., Corfu, F., Griffin, W.L., Meier, M., Oberli, F., Vonquadt, A., Roddick, J.C., Speigel, W. 1995. Three natural zircon standards for U-Th-Pb, Lu-Hf, trace element and REE analyses. Geostandards and Geoanalytical Research 19, 1-23.

Woodhead, J.D., Hergt, J.M., 2005. A preliminary appraisal of seven natural zircon reference materials for in situ isotope determination. Geostandards and Geoanalytical Research 29, 183-195.

Woodhead, J., Hergt, J., Shelley, M., Eggins, S., Kemp, R., 2004. Zircon Hf-isotope analysis with an excimer laser, depth profiling, ablation of complex geometries, and concomitant age estimation. Chemical Geology 209, 121-135.

Zhang, S., Li, Z.X., Evans, D.A., Wu, H., Li, H., Dong, J., 2012. Pre-Rodinia supercontinent Nuna shaping up: a global synthesis with new paleomagnetic results from North China. Earth and Planetary Science Letters 353, 145-155.

\section{Appendix 1 - Analytical techniques}

U-Pb geochronology 
Zircon separation techniques

Approximately 3 to $5 \mathrm{~kg}$ of rock material for each sample was crushed and disintegrated using disc mill to obtain grain fraction between ca. 50-500 $\mu \mathrm{m}$ in size. The milled samples were sieved to obtain the size fraction $<315 \mu \mathrm{m}$ and this fraction was processed by using the Wilfley table in order to concentrate the heavy minerals. The heavy fraction of the samples was loaded to sodium polytungstate (SPT) and subsequently to diiodomethane (DIM) heavy liquids, followed by removal of the magnetic minerals from the heavy fraction using the Frantz isodynamic separator.

Zircon imaging and LA-ICP-MS techniques

1) Zircons were arranged in rows, cast into epoxy resin discs having a diameter of $2.54 \mathrm{~cm}$, and polished to reveal grain centers. Prior to analysis, cathodoluminescence and transmitted images were obtained so that the best sites for analysis could be chosen. Zircon analyses were performed using a Neptune multicollector inductively coupled plasma mass spectrometer (ICP-MS) and an Analyte G2 excimer laser ablation (LA) system. Table S1 provides the cup and ICP-MS configuration as well as the laser parameters used during the analysis. The analyses were conducted by groups of 13 samples, each sample providing 40 sequential measurements (integration time ca. $1 \mathrm{~s} /$ cycle). The U-Pb analysis was done in the following order: two blanks, two NIST standard glasses, three external standards, 13 unknown samples, two external standards and two blanks. An interpolation of the four blank measurement sequences, two before and two after the samples (bracketing method), was subtracted from each one of the seven measured masses (202, 204, 206, 207, 208, 232 and 238).

The ${ }^{235} \mathrm{U}$ isotope was not measured but mathematically calculated using the relative abundance ${ }^{238} \mathrm{U} /{ }^{235} \mathrm{U}=137.88$. The ${ }^{204} \mathrm{Hg}$ interference for ${ }^{204} \mathrm{~Pb}$ was corrected thanks to the ${ }^{202} \mathrm{Hg}$, assuming ${ }^{204} \mathrm{Hg} /{ }^{202} \mathrm{Hg}=4.350360$. Using the partially corrected ${ }^{207} \mathrm{~Pb} /{ }^{206} \mathrm{~Pb}$ ratio as an estimative for the age and the formulas of Stacey and Kramers (1975), the ${ }^{206} \mathrm{~Pb} /{ }^{204} \mathrm{~Pb}$, ${ }^{207} \mathrm{~Pb} /{ }^{204} \mathrm{~Pb}$ and ${ }^{208} \mathrm{~Pb} /{ }^{204} \mathrm{~Pb}$ relative abundances (variable with the geological age) were thus calculated. The common $\mathrm{Pb}$ (non-radiogenic) fraction of the isotopes ${ }^{206} \mathrm{~Pb},{ }^{207} \mathrm{~Pb}$ and ${ }^{208} \mathrm{~Pb}$ could then be discounted, by subtracting from each one the ${ }^{204} \mathrm{~Pb}$ signal multiplied, respectively, by the three relative abundances calculated before. Another bracketing of measurements (two sequences before and after samples) from NIST-612 standards was also used to convert the three total signals $\left(\mathrm{Pb}={ }^{204} \mathrm{~Pb}+{ }^{206} \mathrm{~Pb}+{ }^{207} \mathrm{~Pb}+{ }^{208} \mathrm{~Pb} ; \quad \mathrm{Th}={ }^{232} \mathrm{Th}\right.$; $\left.\mathrm{U}={ }^{235} \mathrm{U}+{ }^{238} \mathrm{U}\right)$ in ppm units.

A final bracketing (three before and two after samples) of the GJ-1 standard (Jackson et al., 2004) was then used to correct the effect of the fractionation on the four ratios $\left({ }^{206} \mathrm{~Pb} /{ }^{238} \mathrm{U}\right.$, ${ }^{207} \mathrm{~Pb} /{ }^{235} \mathrm{U},{ }^{207} \mathrm{~Pb} /{ }^{206} \mathrm{~Pb},{ }^{208} \mathrm{~Pb} /{ }^{232} \mathrm{Th}$ ), before they could be finally be extrapolated through best line fits to $\mathrm{t}=0$ and then used to calculate the respective ages. Errors in all simple arithmetic operations were algebraically propagated, e.g., $d(A-B)=d A+d B \quad$ and $d(A / B) /(A / B)=d A / A+d B / B$. Least squares fitting was the choice for the best line fits and, on 
all final results and plots, it was adopted the error framework (at the $2 \sigma$ level) already available in Isoplot 3.70 (Ludwig, 2008).

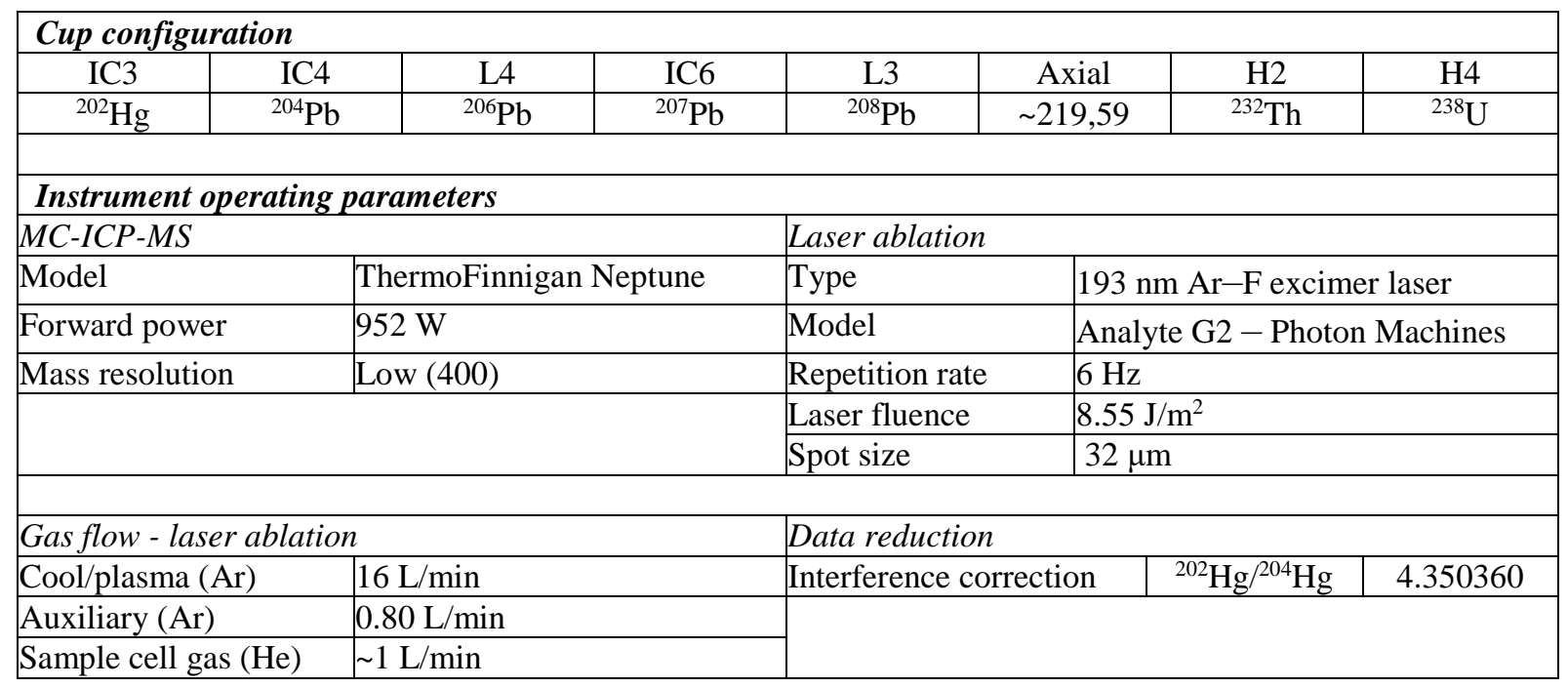

Table S1. Cup configuration and instrument operating parameters for U-Pb LA-ICP-MS analyses.

2) Zircon was transferred in ethanol from the pool of separated grains to a double-sided tape using pipette and mounted in 1 inch epoxy-filled blocks and polished using $\mathrm{SiC}$ and diamond paste to obtain even surfaces suitable for cathodoluminescence imaging and laser ablation ICP-MS analysis. Cathodoluminescence images of zircon were obtained using the Zeiss Supra $55 \mathrm{VP}$ scanning electron microscope at the University of Bergen. Prior to U-Pb analysis, the carbon coating was removed and the sample surfaces were cleaned with $2 \%$ $\mathrm{HNO}_{3}$, DI water, and ethanol. The ICP-MS U-Pb analyses were performed using different instrumental setups with minor variations across 3 years and multiple analytical sessions. Sample UC 11 was analysed at the University of Bergen, Norway using $\mathrm{Nu}$ AttoM high resolution ICP-MS coupled to a $193 \mathrm{~nm}$ ArF excimer laser (Resonetics RESOlution M-50 LR). The LA conditions were set to $26 \mu \mathrm{m}$ spot size, laser energy of ca $4.1 \mathrm{~J} / \mathrm{cm}^{2}$, repetition rate of $5 \mathrm{~Hz}$, flow of the He carrier gas at $730 \mathrm{ml} / \mathrm{min}\left(+5 \mathrm{ml} / \mathrm{min} \mathrm{N}_{2}\right)$. The timing of the individual analyses was set to $15 \mathrm{~s}$ of gas blank and $30 \mathrm{~s}$ of zircon ablation followed by $25 \mathrm{~s}$ of cell wash-out.

3) Sample UC 10 was analysed at the Institute of Geology of the Czech Academy of Sciences, Prague, Czech Republic using Thermo Scientific Element 2 sector field ICP-MS coupled to a $193 \mathrm{~nm}$ ArF excimer laser (Teledyne Cetac Analyte Excite laser). The LA conditions were set to $25 \mu \mathrm{m}$ spot size, laser energy of ca $3.2 \mathrm{~J} / \mathrm{cm}^{2}$, repetition rate of $5 \mathrm{~Hz}$, flow of the $\mathrm{He}$ carrier gas at $730 \mathrm{ml} / \mathrm{min}\left(+4 \mathrm{ml} / \mathrm{min} \mathrm{N}_{2}\right)$. The timing of the individual analyses was set to $15 \mathrm{~s}$ of gas blank and $35 \mathrm{~s}$ of zircon ablation followed by $35 \mathrm{~s}$ of cell wash-out.

The $\mathrm{U}$ and $\mathrm{Pb}$ signals from the ablated zircon grains were acquired in time resolved peak jumping - pulse counting / analogue mode with 1 point measured per peak for masses 
${ }^{204} \mathrm{~Pb}+\mathrm{Hg},{ }^{206} \mathrm{~Pb},{ }^{207} \mathrm{~Pb},{ }^{208} \mathrm{~Pb},{ }^{232} \mathrm{Th},{ }^{235} \mathrm{U}$, and ${ }^{238} \mathrm{U}$. Due to a non-linear transition between the counting and analogue (attenuated) acquisition modes of the ICP instruments, the raw data were pre-processed using a purpose-made Excel macro. As a result, the intensities of ${ }^{238} \mathrm{U}$ were left unchanged if measured in a counting mode and recalculated from $235 \mathrm{U}$ intensities if the ${ }^{238} \mathrm{U}$ was acquired in analogue (attenuated) mode. Data reduction was then carried out off-line using the Iolite data reduction package version 3.0 with VizualAge utility (Petrus and Kamber 2012). Full details of the data reduction methodology can be found in Paton et al. (2010). The data reduction included correction for gas blank, laser-induced elemental fractionation of $\mathrm{Pb}$ and $\mathrm{U}$ and instrument mass bias. For the data presented here, blank intensities and instrumental bias were interpolated using an automatic spline function while down-hole inter-element fractionation was corrected using an exponential function. No common $\mathrm{Pb}$ correction was applied to the data due to the high $\mathrm{Hg}$ contamination of the commercially available He carrier gas, which precludes accurate correction of the interfering

${ }^{204} \mathrm{Hg}$ on the very small signal of ${ }^{204} \mathrm{~Pb}$ (common lead). Primary concentrations of common $\mathrm{Pb}$ in zircon are considered very low and were controlled by observing the ${ }^{206} \mathrm{~Pb} /{ }^{204} \mathrm{~Pb}$ (radiogenic/common lead) ratio. Analyses with low values were examined (if present) in more detail.

Residual elemental fractionation and instrumental mass bias were corrected by normalization to the natural zircon reference material GJ-1 (Jackson et al., 2004). Zircon reference materials 91500 (Wiedenbeck et al., 1995) and Plešovice (Sláma et al., 2008) were periodically analysed during the measurements for quality control. The mean Concordia age values ranging from $1059 \pm 7 \mathrm{Ma}(2 \sigma)$ to $1077 \pm 16 \mathrm{Ma}(2 \sigma)$ for 91500 and from $337 \pm 5 \mathrm{Ma}$ $(2 \sigma)$ to $338 \pm 3 \mathrm{Ma}(2 \sigma)$ for Plešovice obtained from analyses performed over the courses of different analytical sessions correspond perfectly and are less than $1 \%$ within the published reference values $\left(91500:{ }^{207} \mathrm{~Pb} /{ }^{206} \mathrm{~Pb}\right.$ age of $1065.4 \pm 0.3 \mathrm{Ma}$, Wiedenbeck et al., 1995; Plešovice: ${ }^{206} \mathrm{~Pb} /{ }^{238} \mathrm{U}$ age of $337.1 \pm 0.4 \mathrm{Ma}$, Sláma et al., 2008).

\section{Lu-Hf isotopes}

All Lu-Hf zircon analyses were carried out at the Institute of Geosciences, University of São Paulo on a Neptune multicollector inductively coupled plasma mass spectrometer equipped with an Analyte G2 excimer laser ablation system. Lu-Hf isotopic analyses were performed in the same zircon grains that were previously dated by $\mathrm{U}-\mathrm{Pb}$. The laser spot parameters were: $39 \mu \mathrm{m}$ in diameter; ablation time of $60 \mathrm{~s}$; repetition rate of $7 \mathrm{~Hz}$ and $\mathrm{He}$ was used as the carrier gas. Cup configuration and instrument operating parameters are presented in Table S2. The 9 isotopes: ${ }^{171} \mathrm{Yb},{ }^{173} \mathrm{Yb},{ }^{174}(\mathrm{Hf}+\mathrm{Yb}+\mathrm{Lu}),{ }^{175} \mathrm{Lu},{ }^{176}(\mathrm{Hf}+\mathrm{Yb}+\mathrm{Lu})$, ${ }^{177} \mathrm{Hf},{ }^{178} \mathrm{Hf},{ }^{179} \mathrm{Hf}$ and ${ }^{181}$ Ta were collected simultaneously, on Faraday cups.

Isobaric interferences of ${ }^{176} \mathrm{Yb}$ and ${ }^{176} \mathrm{Lu}$ on ${ }^{176} \mathrm{Hf}$ constituted an analytical challenge, particularly in the case of ${ }^{176} \mathrm{Yb}$, due to its abundance in zircons (Fisher et al., 2014). For the

${ }^{176} \mathrm{Yb}$ mass fractionation corrections, two interference-free $\mathrm{Yb}$ masses were measured $\left({ }^{171} \mathrm{Yb}\right.$ and ${ }^{173} \mathrm{Yb}$ ) and the exponential correction factor $\beta \mathrm{Yb}$ was calculated, following the approach of Woodhead et al. (2004). The same was done for the ${ }^{176} \mathrm{Hf}$, whose correction factor $\beta_{\mathrm{Hf}}$ 
was obtained through the ${ }^{177} \mathrm{Hf}$ and ${ }^{179} \mathrm{Hf}$ measured masses. ${ }^{176} \mathrm{Lu}$ mass fractionation was corrected adopting $\beta_{\mathrm{Lu}}=\beta \mathrm{Hf}$, as this element only has one interference-free isotope $\left({ }^{175} \mathrm{Lu}\right) . \mathrm{A}$ decay constant for ${ }^{176} \mathrm{Lu}$ of $1.867 \times 10^{-11} \mathrm{a}^{-1}$ (Söderlund et al., 2004), the present-day chondritic ratios of ${ }^{176} \mathrm{Hf} /{ }^{177} \mathrm{Hf}=0.282772$ and ${ }^{176} \mathrm{Lu} /{ }^{177} \mathrm{Hf}=0.0332$ (Blichert-Toft and Albarède, 1997) and the depleted mantle values of ${ }^{176} \mathrm{Hf} /{ }^{177} \mathrm{Hf}=0.283225$ and ${ }^{176} \mathrm{Lu} /{ }^{177} \mathrm{Hf}=0.038512$ (Vervoort and Blichert-Toft, 1999) were adopted to calculate $\varepsilon_{\mathrm{Hf}}$ values. A two-stage continental model age was calculated considering ${ }^{176} \mathrm{Lu} /{ }^{177} \mathrm{Hf}=0.0150$ for bulk earth (Griffin et al., 2002).

Between 4 and 10 spot measurements were carried out in the GJ-1 and Mud Tank international standards in parallel with each measured sample, yielding values within experimental error that are comparable to those measured in the Australian National University (Table S3). These results are presented alongside the measured data, and attest the external reproducibility of the new analyses. Furthermore, a comparison of both ${ }^{176} \mathrm{Lu} /{ }^{177} \mathrm{Hf}$ vs. ${ }^{176} \mathrm{Hf} /{ }^{177} \mathrm{Hf}$ and ${ }^{176} \mathrm{Yb} /{ }^{177} \mathrm{Hf}$ vs. ${ }^{176} \mathrm{Hf} /{ }^{177} \mathrm{Hf}$ using the values measured for each sample and for the standards show a random distribution $\left(\mathrm{R}^{2}<0.1\right)$, indicating that the interference corrections of ${ }^{176} \mathrm{Yb}$ and ${ }^{176} \mathrm{Lu}$ on ${ }^{176} \mathrm{Hf}$ were correctly carried out (Fisher et al. 2014).

\begin{tabular}{|c|c|c|c|c|c|c|c|c|c|}
\hline \multicolumn{10}{|c|}{ Cup configuration and interferences } \\
\hline L4 & L3 & $\mathrm{L} 2$ & L1 & Axial & H1 & $\mathrm{H} 2$ & \multicolumn{2}{|c|}{$\mathrm{H} 3$} & $\mathrm{H} 4$ \\
\hline${ }^{171} \mathrm{Yb}$ & ${ }^{173} \mathrm{Yb}$ & $\begin{array}{l}{ }^{174} \mathrm{Hf}, \\
{ }^{174} \mathrm{Yb}, \\
{ }^{174} \mathrm{Lu}\end{array}$ & ${ }^{175} \mathrm{Lu}$ & $\begin{array}{l}{ }^{176} \mathrm{Hf}, \\
{ }^{176} \mathrm{Yb}, \\
{ }^{176} \mathrm{Lu}\end{array}$ & ${ }^{177} \mathrm{Hf}$ & ${ }^{178} \mathrm{Hf}$ & \multicolumn{2}{|c|}{${ }^{179} \mathrm{Hf}$} & ${ }^{181} \mathrm{Ta}$ \\
\hline \multicolumn{10}{|c|}{ Instrument operating parameters } \\
\hline \multicolumn{4}{|c|}{$M C-I C P-M S$} & \multicolumn{6}{|c|}{ Laser ablation } \\
\hline \multicolumn{2}{|l|}{ Model } & \multicolumn{2}{|c|}{ ThermoFinnigan Neptune } & \multicolumn{2}{|c|}{ Type } & \multicolumn{4}{|c|}{$193 \mathrm{~nm} \mathrm{Ar}-\mathrm{F}$ excimer laser } \\
\hline \multicolumn{2}{|c|}{ Forward power } & \multicolumn{2}{|c|}{$952 \mathrm{~W}$} & \multicolumn{2}{|l|}{ Model } & \multicolumn{4}{|c|}{ Analyte G2 - Photon Machines } \\
\hline \multirow{3}{*}{\multicolumn{2}{|c|}{ Mass resolution }} & \multicolumn{2}{|c|}{ Low (400) } & \multicolumn{2}{|c|}{ Repetition rate } & \multicolumn{4}{|c|}{$7 \mathrm{~Hz}$} \\
\hline & & & & \multicolumn{2}{|c|}{ Laser fluence } & \multicolumn{4}{|c|}{$8.55 \mathrm{~J} / \mathrm{m}^{2}$} \\
\hline & & & & \multicolumn{2}{|l|}{ Spot size } & \multicolumn{4}{|c|}{$47 \mu \mathrm{m}$} \\
\hline \multicolumn{4}{|c|}{ Gas flow - laser ablation } & \multicolumn{6}{|c|}{ Data reduction } \\
\hline \multirow{2}{*}{\multicolumn{2}{|c|}{ Cool/plasma (Ar) }} & \multirow{2}{*}{\multicolumn{2}{|c|}{$16 \mathrm{~L} / \mathrm{min}$}} & \multirow{2}{*}{\multicolumn{2}{|c|}{ Mass bias }} & \multicolumn{2}{|c|}{${ }^{173} \mathrm{Yb} /{ }^{171} \mathrm{Yb}$} & \multicolumn{2}{|c|}{1.123456} \\
\hline & & & & & & ${ }^{179} \mathrm{Hf} /{ }^{1}$ & & & 7325 \\
\hline \multicolumn{2}{|c|}{ Auxiliary (Ar) } & \multicolumn{2}{|c|}{$0.80 \mathrm{~L} / \mathrm{min}$} & \multirow{4}{*}{\multicolumn{2}{|c|}{ Interference correction }} & ${ }^{176} \mathrm{Yb} /{ }^{1}$ & & & 86956 \\
\hline Sample ce & is $(\mathrm{He})$ & $\sim 1 \mathrm{~L} / \mathrm{mil}$ & & & & ${ }^{176} \mathrm{Lu} /{ }^{1}$ & & & 2655 \\
\hline Nitrooen & & $14 \mathrm{~mL} / \mathrm{s}$ & & & & ${ }^{174} \mathrm{Yb} /{ }^{1}$ & & & 73000 \\
\hline Noirugen & & $1.4 \mathrm{~mL} / \mathrm{I}$ & & & & ${ }^{178} \mathrm{Hf} /{ }^{1}$ & & & 6735 \\
\hline
\end{tabular}

Table S2. Cup configuration and instrument operating parameters for Hf analyses, following guidelines from Fisher et al. (2014). 


\begin{tabular}{|c|c|c|c|c|}
\hline Standard & \multicolumn{2}{|c|}{ International Value } & \multicolumn{2}{c|}{ Geochronological Research Center São Paulo } \\
\hline & ${ }^{176} \mathrm{Hf} /{ }^{177} \mathrm{Hf}$ & ${ }^{176} \mathrm{Lu} /{ }^{177} \mathrm{Hf}$ & ${ }^{176} \mathrm{Hf} /{ }^{177} \mathrm{Hf}$ & ${ }^{176} \mathrm{Lu} /{ }^{177} \mathrm{Hf}$ \\
\hline GJ-1 & 0.282015 & --- & $0.282036 \pm 0.00017, \mathrm{n}=36$ & $0.000301 \pm 0.000010, \mathrm{n}=3$ \\
\hline Mud Tank & 0.282507 & 0.000042 & $0.282550 \pm 0.000071, \mathrm{n}=3$ & $0.000029 \pm 0.000003, \mathrm{n}=3$ \\
\hline
\end{tabular}

Table S3. Comparison of standard international values (Elhlou et al., 2006; Woodhead and Hergt, 2005) with values measured at the Geochronological Research Center of the University of São Paulo in this study.

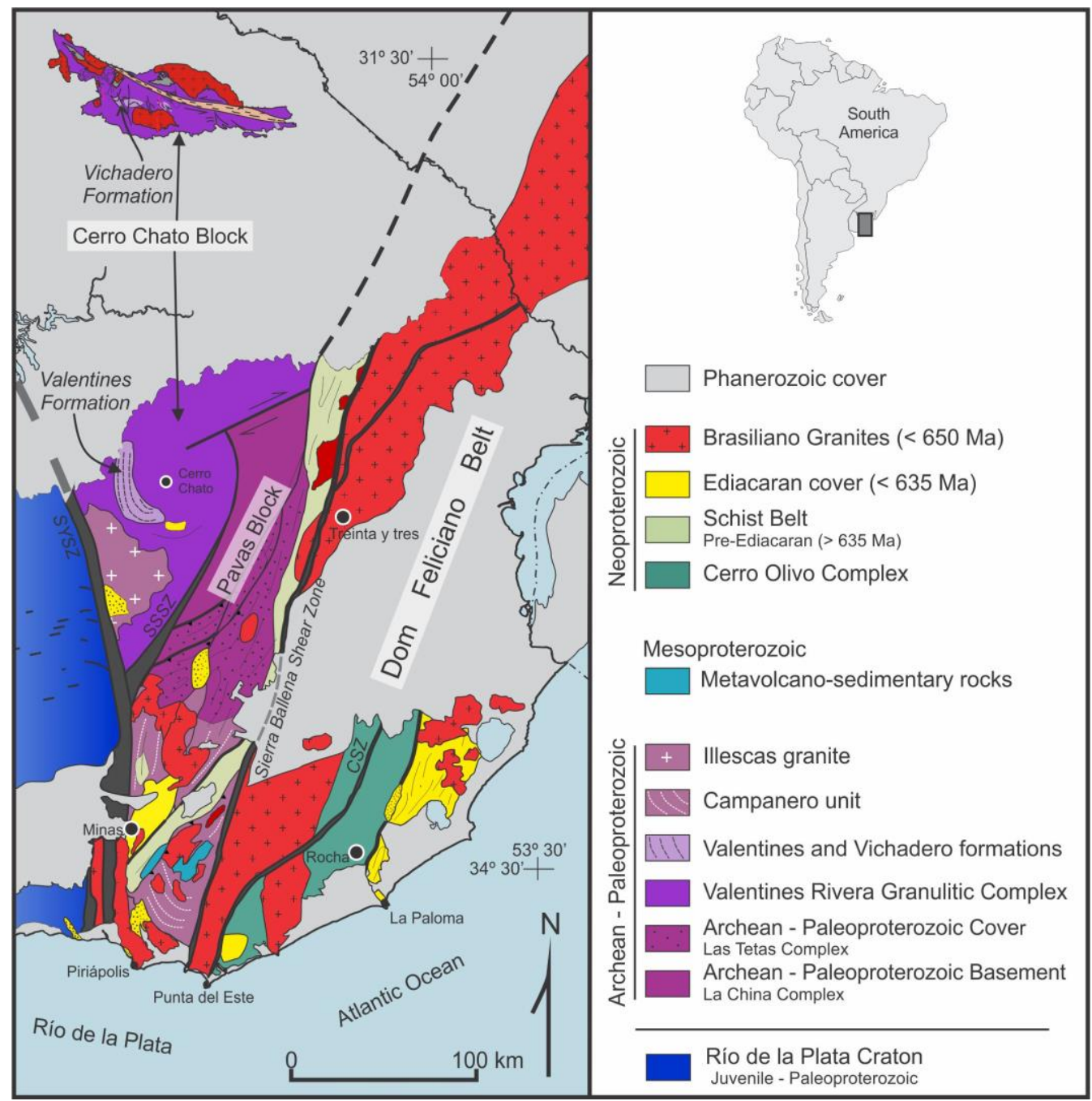

Fig. 1. Geological map of the Nico Pérez Terrane (modified after Oyhantçabal et al., 2011b, 2017; Masquelin et al., 2017; Spoturno et al., in press). 

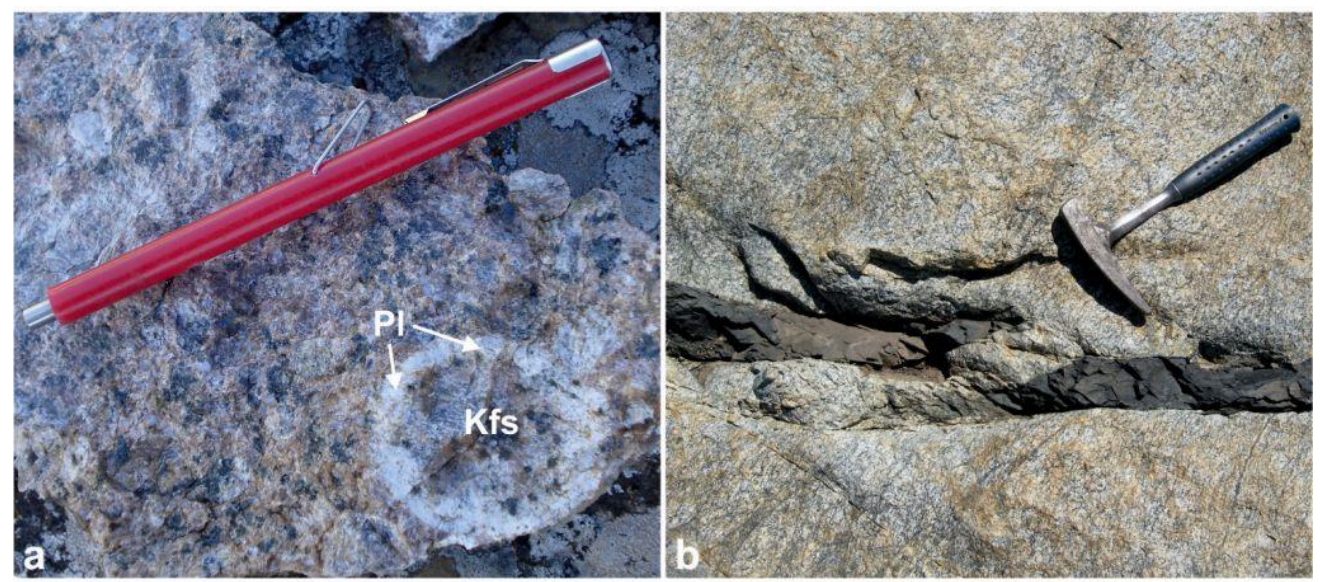

Fig. 2. a) Rapakivi texture of the Illescas granite. b) Felsic orthogneisses of the Campanero Unit, affected by cataclastic deformation and cross-cut by Ediacaran mafic dykes (looking down, top to SE).
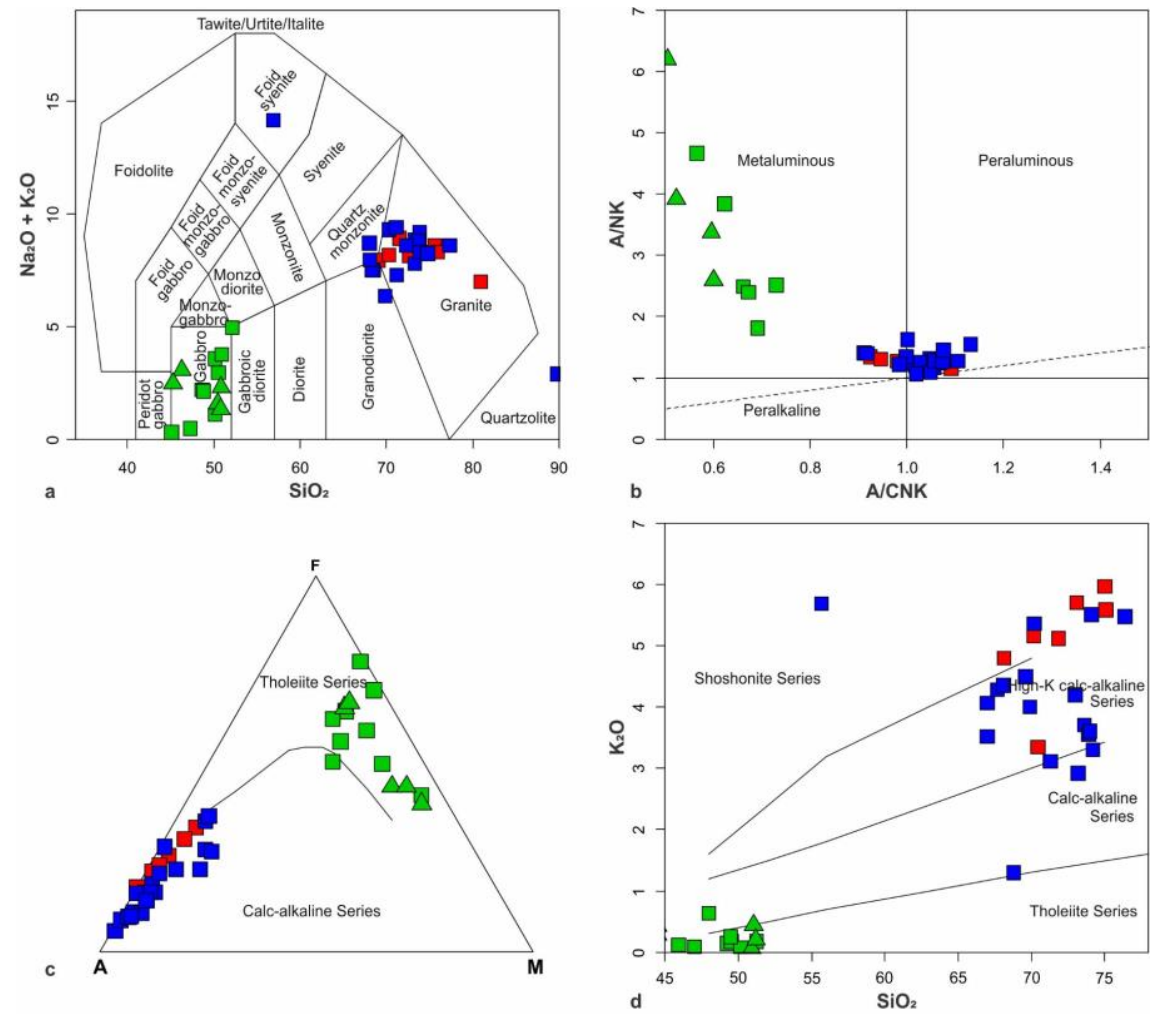

Fig. 3. Major element results. Red: Illescas granite, blue: Campanero Unit, green: metamafic rocks. Squares: this work, triangles: Sánchez Bettucci et al. (2001). a) TAS classification diagram after Middlemost (1994). b) A/CNK vs A/NK plot after Shand (1943). c) AFM diagram after Irvine and Baragar (1971). d) $\mathrm{SiO}_{2}$ vs. $\mathrm{K}_{2} \mathrm{O}$ diagram after Peccerillo and Taylor (1976). 

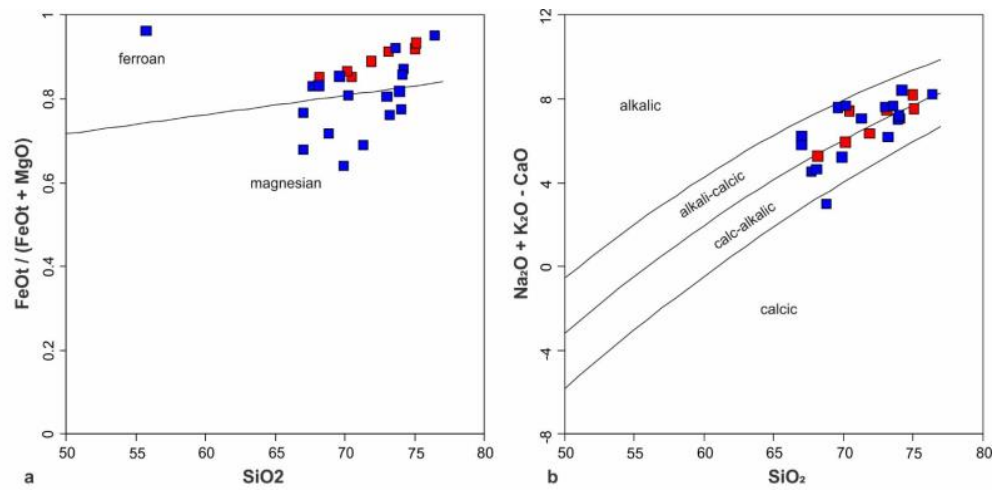

Fig. 4. a) $\mathrm{SiO}_{2}$ vs Fe* index $=\mathrm{FeO}_{\mathrm{t}} /\left(\mathrm{FeO}_{\mathrm{t}}+\mathrm{MgO}\right)$ after Frost et al. (2001). b) $\mathrm{SiO}_{2}$ vs MALI index $=\mathrm{Na}_{2} \mathrm{O}+\mathrm{K}_{2} \mathrm{O}-\mathrm{CaO}$ after Frost et al. (2001). Red: Illescas granite, blue: Campanero Unit, green: metamafic rocks. Squares: this work, triangles: Sánchez Bettucci et al. (2001).
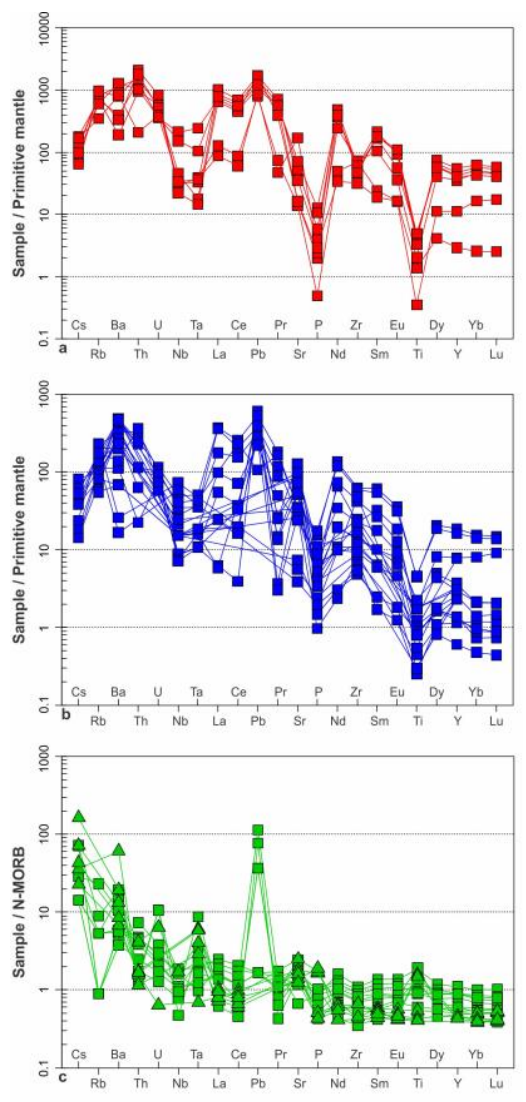

Fig. 5. Multielement spider plots. Red: Illescas granite, blue: Campanero Unit, green: metamafic rocks. Squares: this work, triangles: Sánchez Bettucci et al. (2001). a) Illescas granite (primitive mantle composition after McDonough and Sun, 1995). b) Campanero Unit orthogneisses (primitive mantle composition after McDonough and Sun, 1995). c) Metagabbros (N-MORB composition after Sun and McDonough, 1989). 

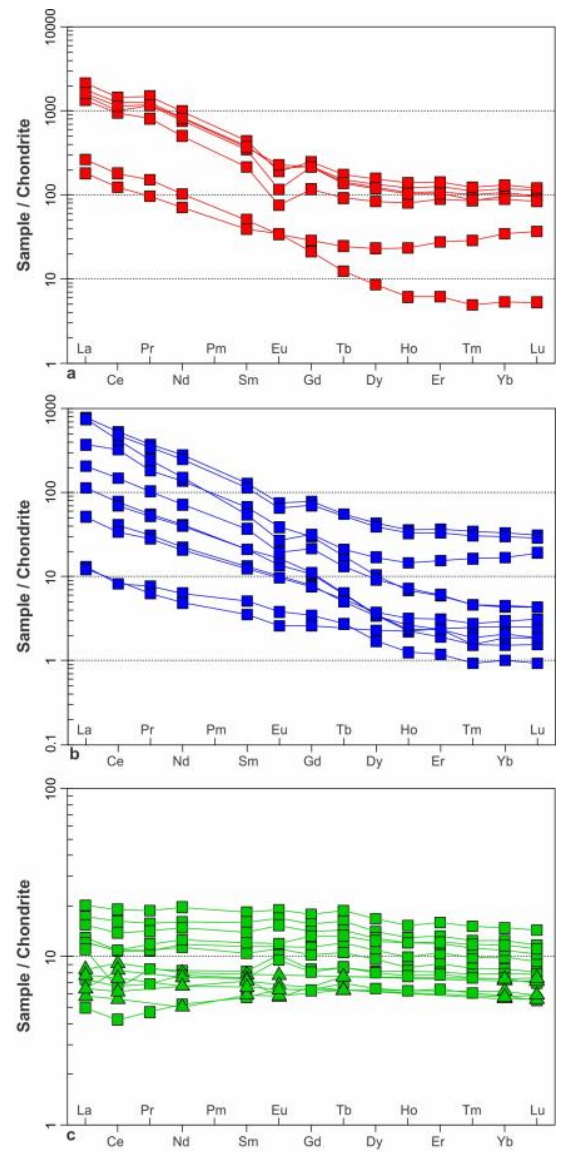

Fig. 6. Chondrite-normalized REE plots (chondrite composition after Boynton, 1984). Red: Illescas granite, blue: Campanero Unit, green: metamafic rocks. Squares: this work, triangles: Sánchez Bettucci et al. (2001).

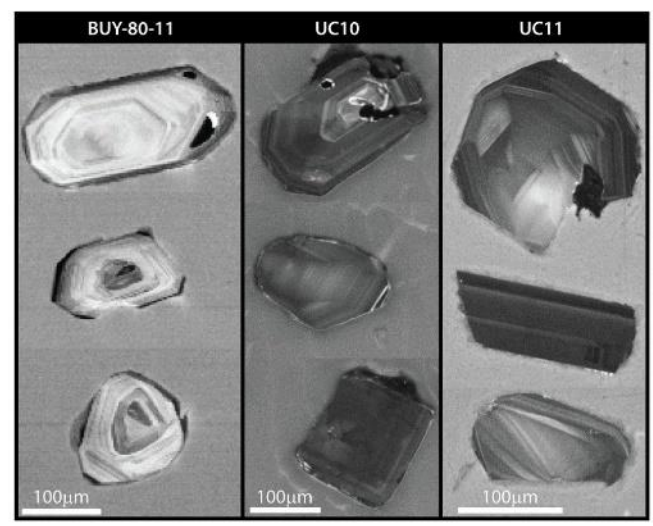

Fig. 7. Cathodoluminiscence images of representative zircons (scale: $100 \mu \mathrm{m}$ ). 

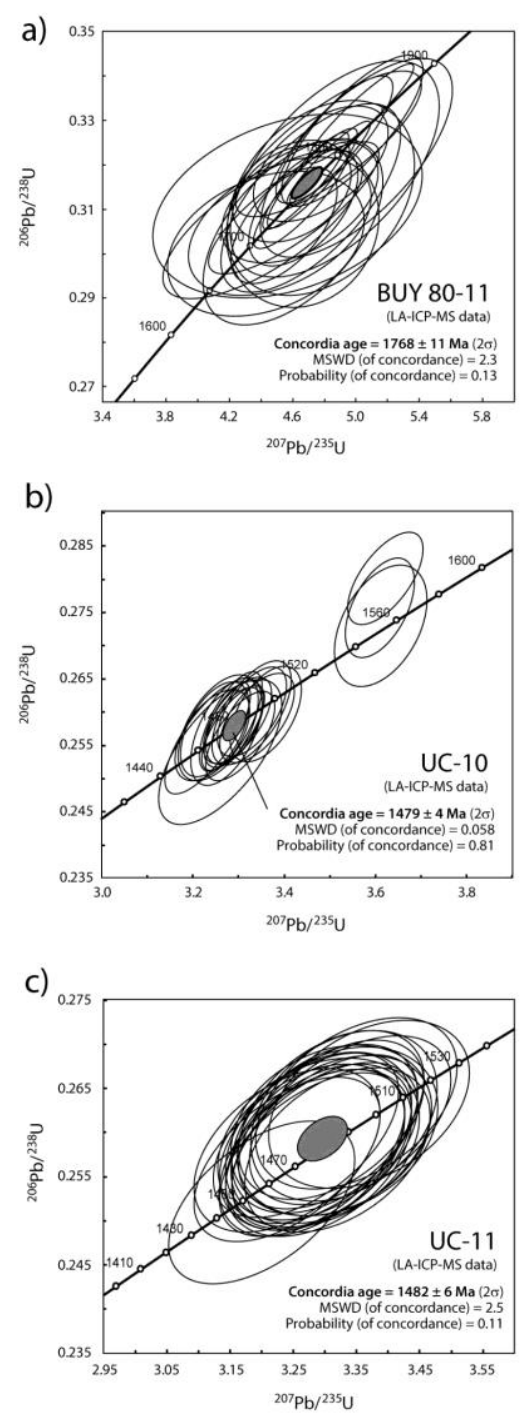

Fig. 8. U-Pb diagrams (BUY 80-11: Illescas granite, UC-10: metagabbro, UC-11: metagabbro). All errors depicted at $2 \sigma$ level. 


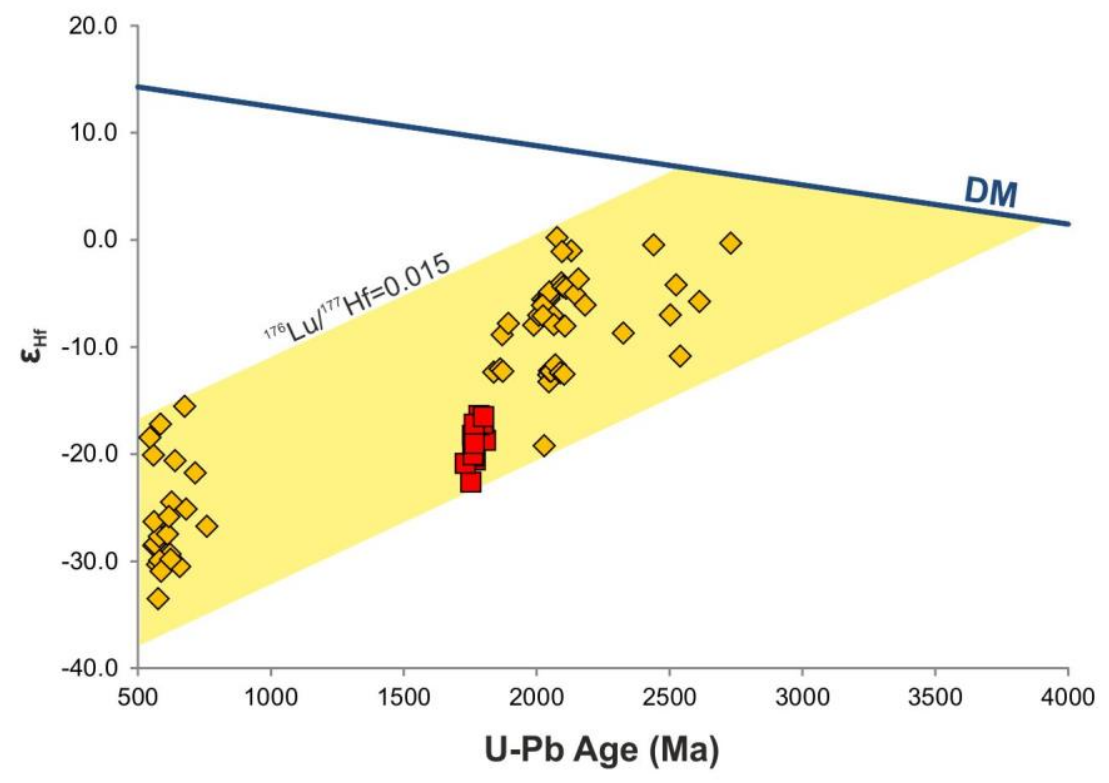

Fig. 9. U-Pb vs. $\varepsilon_{\mathrm{Hf}}$ zircon data for the Illescas granite (red squares). Data of orthogneisses of the Paleoproterozoic Valentines-Rivera Granulitic Complex and Neoproterozoic granitoids of the Nico Pérez Terrane are also included (orange diamonds; recalculated after Oriolo et al., 2016a). Data were recalculated considering a constant decay $\lambda^{176} \mathrm{Lu}=1.867 \times 10^{-}$ 11 year ${ }^{-1}$ (Söderlund et al., 2004) and CHUR values of ${ }^{176} \mathrm{Hf} /{ }^{177} \mathrm{Hf}=0.282772$ and ${ }^{176} \mathrm{Lu} /{ }^{177} \mathrm{Hf}=0.0332$ (Blichert-Toft and Albarède, 1997). The yellow area indicates a crustal array with ${ }^{176} \mathrm{Lu} /{ }^{177} \mathrm{Hf}=0.015$, typical for a crustal reservoir (e.g., Griffin et al., 2002).

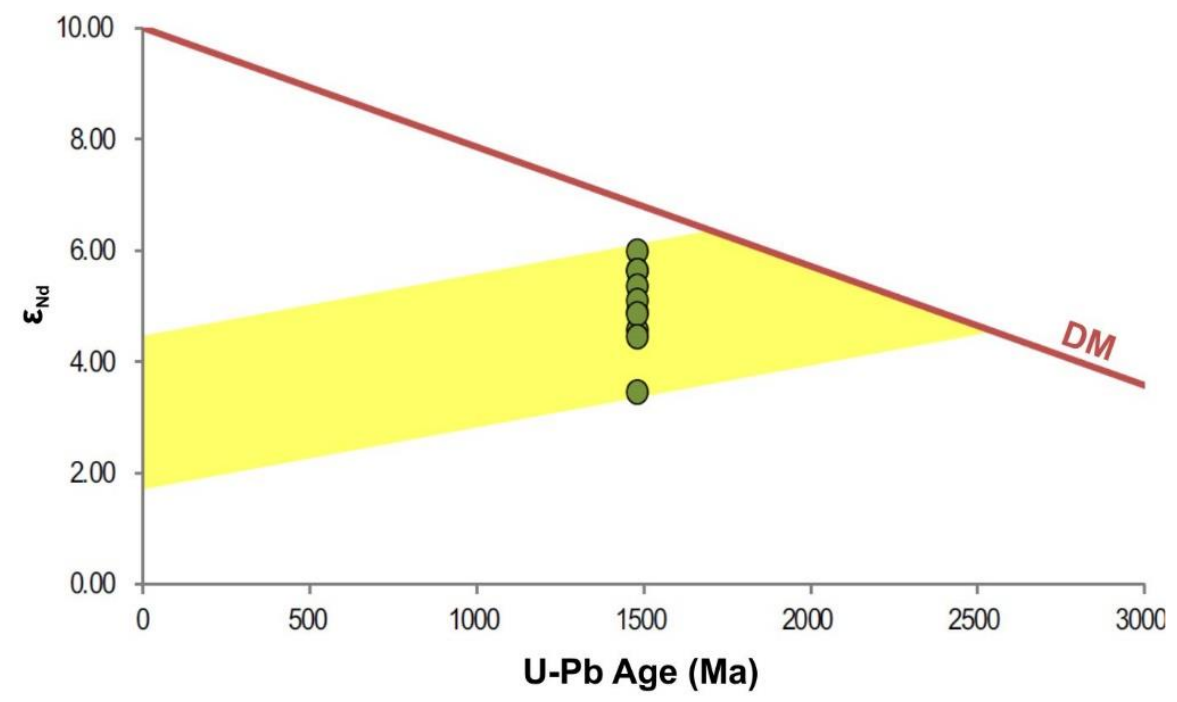

Fig. 10. U-Pb vs. $\varepsilon_{\mathrm{Nd}}$ data for metagabbros. Depleted mantle (DM) evolution after Goldstein et al. (1984). 

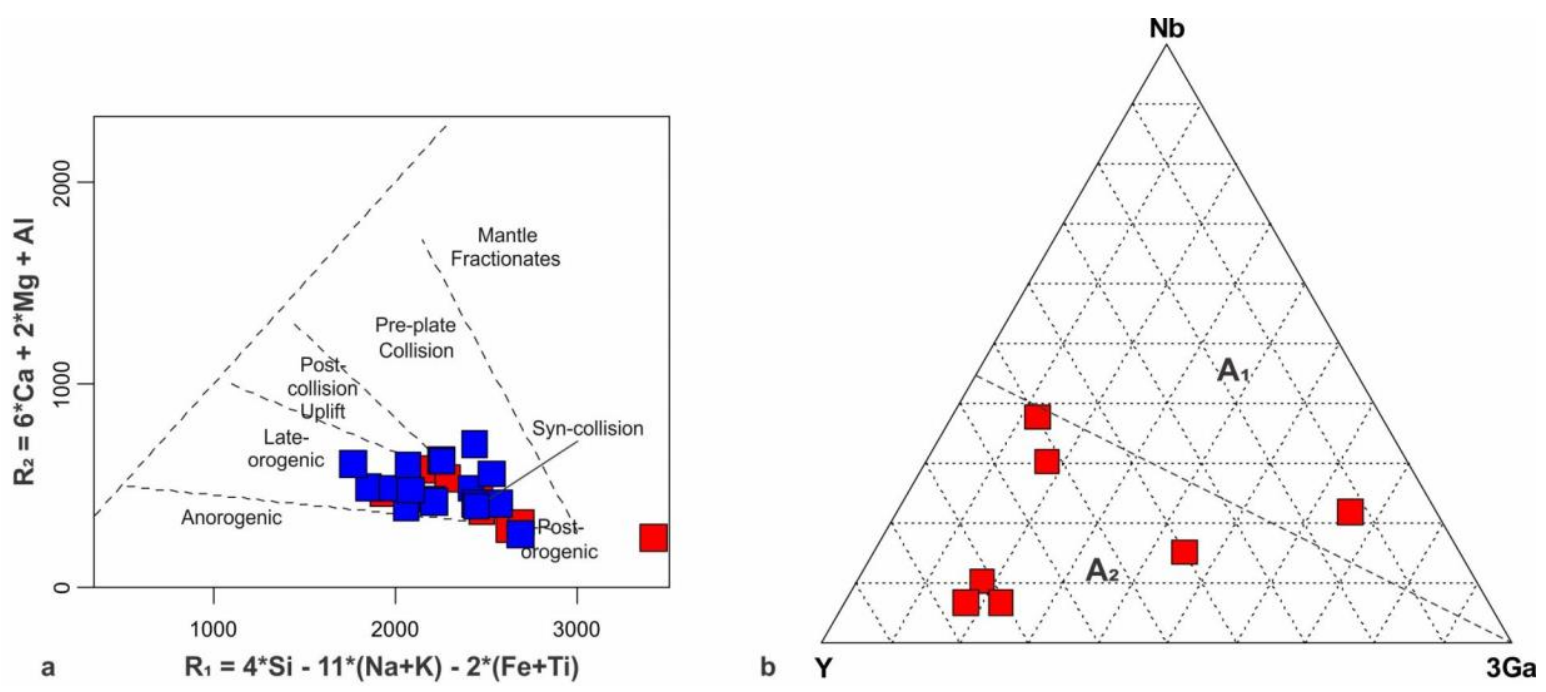

Fig. 11. a) $R_{1}$ vs $R_{2}$ tectonic discrimination diagrams after Batchelor and Bowden (1985). b) Ternary diagram for discrimination of $A_{1^{-}}$and $A_{2}$-type granitoids after Eby (1992). Red: Illescas granite, blue: Campanero Unit.
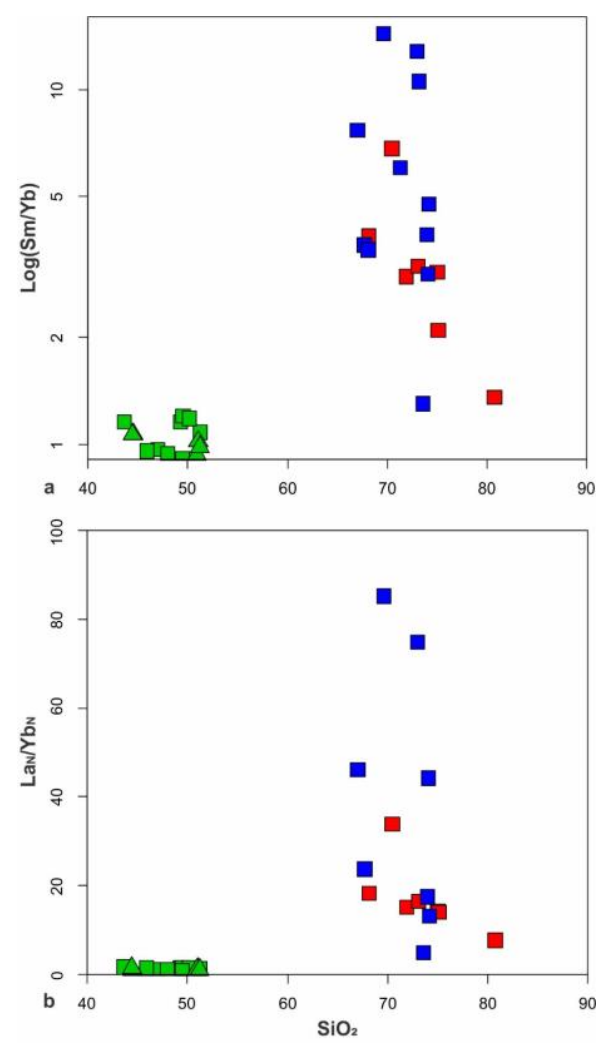

Fig. 12. $\mathrm{SiO}_{2}$ vs crustal thickening proxies $\left(\mathrm{Sm} / \mathrm{Yb}, \mathrm{La}_{\mathrm{N}} / \mathrm{Yb}_{\mathrm{N}}\right)$. Red: Illescas granite, blue: Campanero Unit, green: metamafic rocks. Squares: this work, triangles: Sánchez Bettucci et al. (2001). 

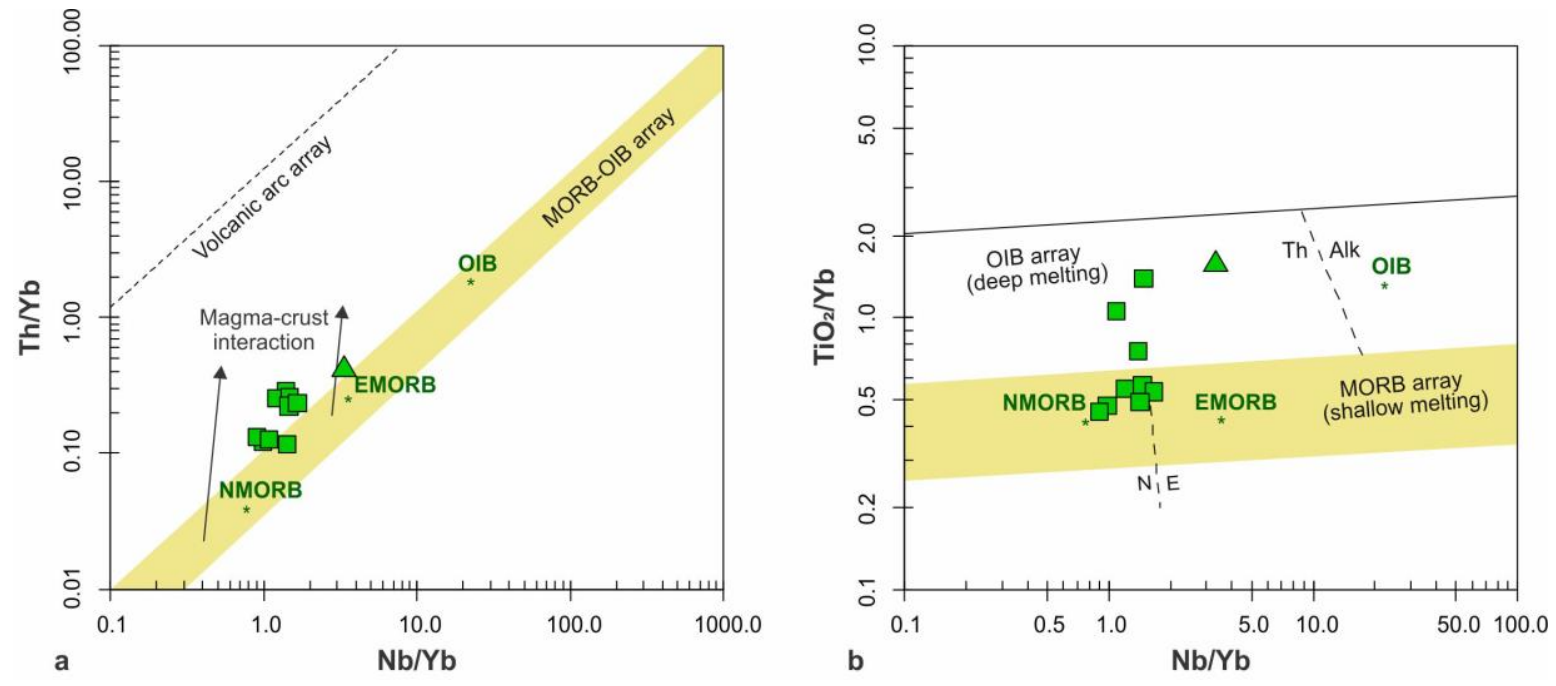

Fig. 13. Discrimination diagrams for Mesoproterozoic basic rocks (after Pearce, 2008). Squares: this work, triangles: Sánchez Bettucci et al. (2001).

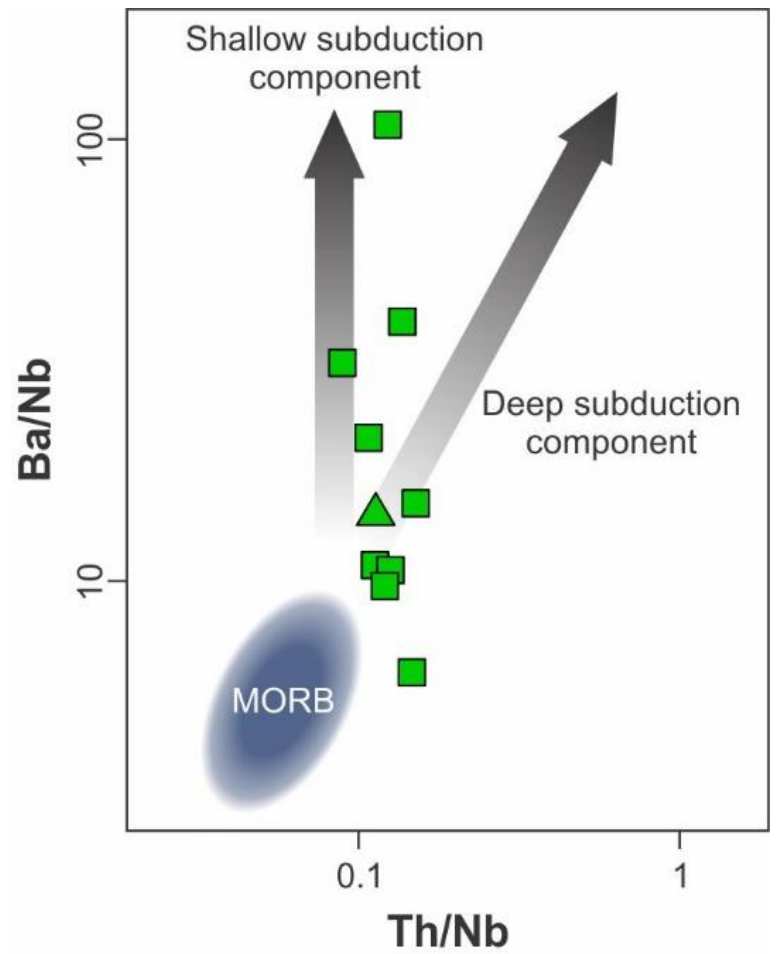

Fig. 14. $\mathrm{Th} / \mathrm{Nb}$ vs. $\mathrm{Ba} / \mathrm{Nb}$ for Mesoproterozoic basic rocks (after Pearce and Stern, 2006). Squares: this work, triangles: Sánchez Bettucci et al. (2001). 


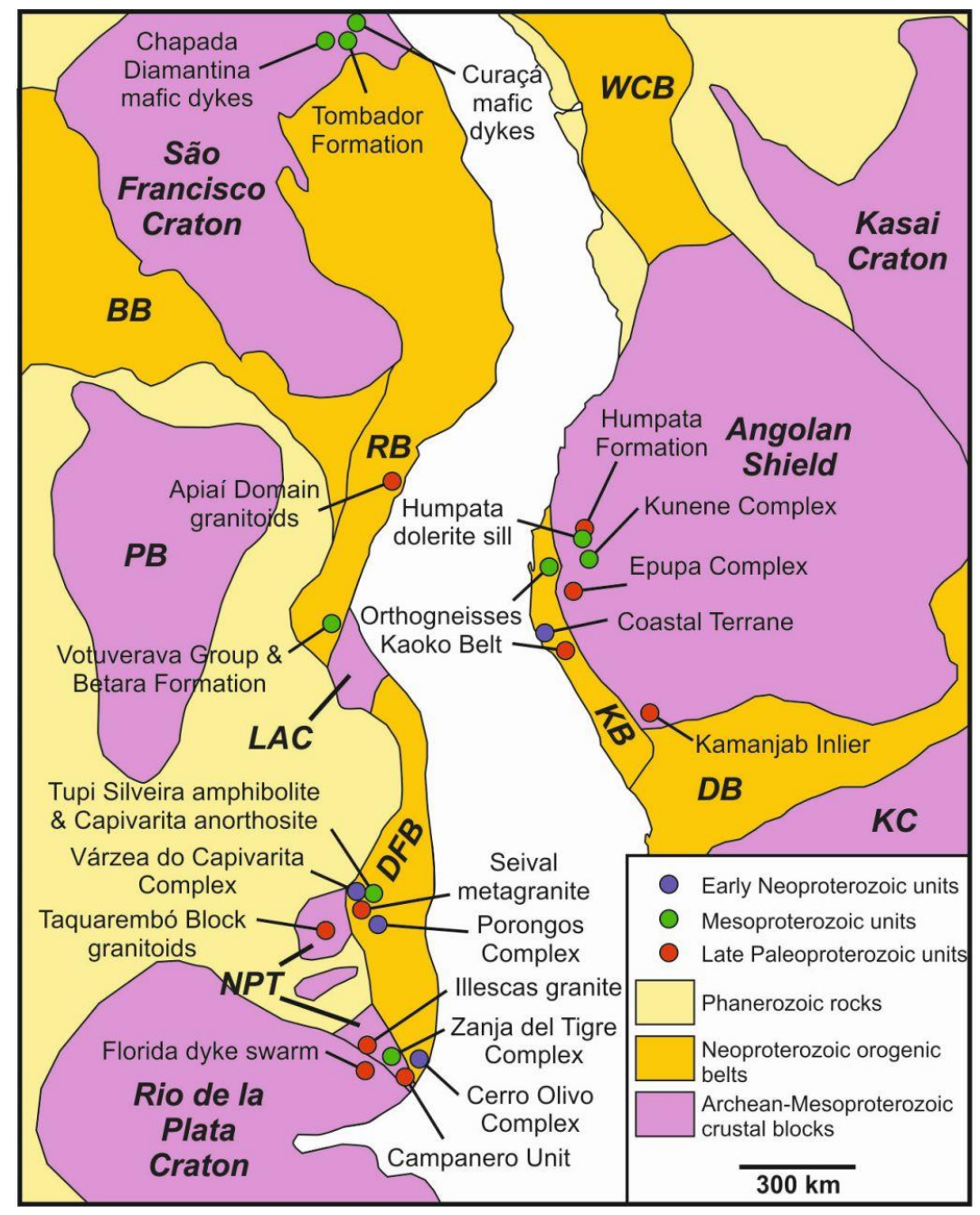

Fig. 15. Sketch map showing late Paleoproterozoic to early Neoproterozoic units along the South Atlantic margin (modified after McCourt et al., 2013; Jelsma et al., 2018; Schmitt et al., 2018). Phanerozoic volcano-sedimentary cover of the basement is not shown. NPT: Nico Pérez Terrane, LAC: Luis Alves and Curitiba terranes, PB: Paranapanema Block, KC: Kalahari Craton, DFB: Dom Feliciano Belt, RB: Ribeira Belt, BB: Brasilia Belt, WCB: West Congo Belt, KB: Kaoko Belt, DB: Damara Belt. See Section 5.3 for details. 